\title{
Prebiotics: Definition, Types, Sources, Mechanisms, and Clinical Applications
}

\author{
Dorna Davani-Davari ${ }^{1}$, Manica Negahdaripour ${ }^{2,3}$, Iman Karimzadeh ${ }^{4}$, Mostafa Seifan ${ }^{5, *}$, \\ Milad Mohkam ${ }^{6}$, Seyed Jalil Masoumi ${ }^{7}$, Aydin Berenjian ${ }^{5}$ and Younes Ghasemi ${ }^{2,3,7,8, *}$ \\ 1 Pharmaceutical Biotechnology Incubator, School of Pharmacy, Shiraz University of Medical Sciences, \\ Shiraz 71348, Iran; d.davani.d@gmail.com \\ 2 Department of Pharmaceutical Biotechnology, School of Pharmacy, Shiraz University of Medical Sciences, \\ Shiraz 71348, Iran; Manica.Negahdaripour@gmail.com \\ 3 Pharmaceutical Sciences Research Center, Shiraz University of Medical Sciences, Shiraz 71348, Iran \\ 4 Department of Clinical Pharmacy, School of Pharmacy, Shiraz University of Medical Sciences, \\ Shiraz 71348, Iran; karimzadehiman@yahoo.com \\ 5 Faculty of Science and Engineering, University of Waikato, Hamilton 3216, New Zealand; \\ Aydin.berenjian@waikato.ac.nz \\ 6 Biotechnology Research Center, Shiraz University of Medical Sciences, Shiraz 71348, Iran; \\ Milad.Mohkam47@yahoo.com \\ 7 Nutrition Research Center, Department of Clinical Nutrition, School of Nutrition and Food Sciences, \\ Shiraz University of Medical Sciences, Shiraz 71348, Iran; J.masoumi74@gmail.com \\ 8 Department of Medical Biotechnology, School of Advanced Medical Sciences and Technologies, \\ Shiraz University of Medical Sciences, Shiraz 71348, Iran \\ * Correspondence: mseifan@waikato.ac.nz (M.S.); ghasemiy@sums.ac.ir (Y.G.); \\ Tel.: +64-07-838-4173 (M.S.); +98-71-324-26729 (Y.G.)
}

Received: 27 February 2019; Accepted: 5 March 2019; Published: 9 March 2019

\begin{abstract}
Prebiotics are a group of nutrients that are degraded by gut microbiota. Their relationship with human overall health has been an area of increasing interest in recent years. They can feed the intestinal microbiota, and their degradation products are short-chain fatty acids that are released into blood circulation, consequently, affecting not only the gastrointestinal tracts but also other distant organs. Fructo-oligosaccharides and galacto-oligosaccharides are the two important groups of prebiotics with beneficial effects on human health. Since low quantities of fructo-oligosaccharides and galacto-oligosaccharides naturally exist in foods, scientists are attempting to produce prebiotics on an industrial scale. Considering the health benefits of prebiotics and their safety, as well as their production and storage advantages compared to probiotics, they seem to be fascinating candidates for promoting human health condition as a replacement or in association with probiotics. This review discusses different aspects of prebiotics, including their crucial role in human well-being.
\end{abstract}

Keywords: prebiotics; gut microbiota; short-chain fatty acids; fructo-oligosaccharides; galacto-oligosaccharides

\section{Introduction}

Various types of microorganisms, known as gut microbiota, are inhabitants of the human gastrointestinal tract. It has been reported that there are $10^{10}-10^{12}$ live microorganisms per gram in the human colon [1]. The resident microbial groups in the stomach, small, and large intestine are crucial for human health. The majority of these microorganisms, which are mostly anaerobes, live in the large intestine [2].

Although some endogenous factors, such as mucin secretions, can affect the microbial balance, human diet is the chief source of energy for their growth. Particularly, non-digestible carbohydrates 
can highly modify the composition and function of gut microbiota [3]. Beneficial intestinal microbes ferment these non-digestible dietary substances called prebiotics and obtain their survival energy from degrading indigestible binds of prebiotics $[4,5]$. As a result of this, prebiotics can selectively influence gut microbiota [6,7]. On the other hand, the gut microbiota affects intestinal functions, such as metabolism and integrity of the intestine. Moreover, they can suppress pathogens in healthy individuals through induction of some immunomodulatory molecules with antagonistic effects against pathogens by lactic acid that is produced by Bifidobacterium and Lactobacillus genera [8-11].

Various compounds have been tested to determine their function as prebiotics. Fructo-oligosaccharides (FOS), galacto-oligosaccharides (GOS), and trans-galacto-oligosaccharides (TOS) are the most common prebiotics. Fermentation of prebiotics by gut microbiota produces short-chain fatty acids (SCFAs), including lactic acid, butyric acid, and propionic acid. These products can have multiple effects on the body. As an example, propionate affects T helper 2 in the airways and macrophages, as well as dendritic cells in the bone marrows [12,13]. SCFAs decrease the $\mathrm{pH}$ of colon $[14,15]$. Peptidoglycan is another prebiotics fermentation product that can stimulate the innate immune system against pathogenic microorganisms $[12,16]$. The structure of prebiotics and the bacterial composition of gut determine the fermentation products $[14,15]$. The effects of prebiotics on human health are mediated through their degradation products by microorganisms. For example, butyrate influences intestinal epithelial development [17]. Since SCFAs can diffuse to blood circulation through enterocytes, prebiotics have the ability to affect not only the gastrointestinal tract but also distant site organs [18].

In this review, we critically elaborate on different aspects of prebiotics, including their definition, types, sources, mechanisms, and clinical applications.

\section{Definition}

The prebiotics concept was introduced for the first time in 1995 by Glenn Gibson and Marcel Roberfroid [4]. Prebiotic was described as "a non-digestible food ingredient that beneficially affects the host by selectively stimulating the growth and/or activity of one or a limited number of bacteria in the colon, and thus improves host health". This definition was almost unchanged for more than 15 years. According to this definition, only a few compounds of the carbohydrate group, such as short and long chain $\beta$-fructans [FOS and inulin], lactulose, and GOS, can be classified as prebiotics. In 2008, the 6th Meeting of the International Scientific Association of Probiotics and Prebiotics (ISAPP) defined "dietary prebiotics" as "a selectively fermented ingredient that results in specific changes in the composition and/or activity of the gastrointestinal microbiota, thus conferring benefit(s) upon host health" [19].

The following criteria are used to classify a compound as a prebiotic: (i) it should be resistant to acidic $\mathrm{pH}$ of stomach, cannot be hydrolyzed by mammalian enzymes, and also should not be absorbed in the gastrointestinal tract, (ii) it can be fermented by intestinal microbiota, and (iii) the growth and/or activity of the intestinal bacteria can be selectively stimulated by this compound and this process improves host's health [19].

Although not all the prebiotics are carbohydrates, the following two criteria can be exploited to distinguish fiber from carbohydrate-derived prebiotics: (i) fibers are carbohydrates with a degree of polymerization (DP) equal or higher than 3 and (ii) endogenous enzymes in the small intestine cannot hydrolyze them. It should be taken into account that the fiber solubility or fermentability is not crucial [20,21].

There are also some revised definitions for prebiotics published in the scientific literature [22]. However, the above-mentioned definition, which was given in 2008 , has been accepted in recent years. Despite the absence of a consensus definition, the important part of the original and other definitions is that the consumption of prebiotics is associated with human well-being. The word "selectivity", or the potency of a prebiotic to stimulate a specific gut microbiota, was another key element of the original definition; however, this concept has been questioned recently [23]. In 2013, Scott et al. [24] 
reported that the prebiotic effect was enhanced by cross-feeding, defined as the product of one species which can be consumed by another one. This implication raises doubt for utilizing the "selectivity" term in the prebiotics definition. A review on the evolution of prebiotics concept through history can be found in a previous publication [23], and the debate on their definition is still ongoing [25].

\section{Types of Prebiotics}

There are many types of prebiotics. The majority of them are a subset of carbohydrate groups and are mostly oligosaccharide carbohydrates (OSCs). The relevant articles are mainly on OSCs, but there are also some pieces of evidence proving that prebiotics are not only carbohydrates.

\subsection{Fructans}

This category consists of inulin and fructo-oligosaccharide or oligofructose. Their structure is a linear chain of fructose with $\beta(2 \rightarrow 1)$ linkage. They usually have terminal glucose units with $\beta(2 \rightarrow 1)$ linkage. Inulin has DP of up to 60, while the DP of FOS is less than 10 [2].

Previously, some studies implicated that fructans can stimulate lactic acid bacteria selectively. However, over recent years, there are some investigations showing that the chain length of fructans is an important criterion to determine which bacteria can ferment them [26]. Therefore, other bacterial species can also be promoted directly or indirectly by fructans.

\subsection{Galacto-Oligosaccharides}

Galacto-oligosaccharides (GOS), the product of lactose extension, are classified into two subgroups: (i) the GOS with excess galactose at $\mathrm{C}_{3}, \mathrm{C}_{4}$ or $\mathrm{C}_{6}$ and (ii) the GOS manufactured from lactose through enzymatic trans-glycosylation. The end product of this reaction is mainly a mixture of tri- to pentasaccharides with galactose in $\beta(1 \rightarrow 6), \beta(1 \rightarrow 3)$, and $\beta(1 \rightarrow 4)$ linkages. This type of GOS is also termed as trans-galacto-oligosaccharides or TOS $[19,27]$.

GOSs can greatly stimulate Bifidobacteria and Lactobacilli. Bifidobacteria in infants have shown high incorporation with GOS. Enterobacteria, Bacteroidetes, and Firmicutes are also stimulated by GOS, but to a lesser extent than Bifidobacteria [2].

There are some GOSs derived from lactulose, the isomer of lactose. This lactulose-derived GOSs are also considered as prebiotics [19]. Besides these types of GOS, the other types are based on sucrose extension named raffinose family oligosaccharides (RFO). The effect of RFO on gut microbiota has not been elucidated yet $[28,29]$.

\subsection{Starch and Glucose-Derived Oligosaccharides}

There is a kind of starch that is resistant to the upper gut digestion known as resistant starch (RS). RS can promote health by producing a high level of butyrate; so it has been suggested to be classified as a prebiotic [30]. Various groups of Firmicutes show the highest incorporation with a high amount of RS [3]. An in vitro study demonstrated that RS could also be degraded by Ruminococcus bromii, and Bifidobacterium adolescentis, and also to a lesser extent by Eubacterium rectale and Bacteroides thetaiotaomicron. However, in the mixed bacterial and fecal incubations, RS degradation is impossible in the absence of R. bromii [31].

Polydextrose is a glucose-derived oligosaccharide. It consists of glucan with a lot of branches and glycosidic linkages. There is some evidence that it can stimulate Bifidobacteria, but it has not been confirmed yet [32].

\subsection{Other Oligosaccharides}

Some oligosaccharides are originated from a polysaccharide known as pectin. This type of oligosaccharide is called pectic oligosaccharide (POS). They are based on the extension of galacturonic acid (homogalacturonan) or rhamnose (rhamnogalacturonan I). The carboxyl groups may 
be substituted with methyl esterification, and the structure can be acetylated at $C_{2}$ or $C_{3}$. Various types of sugars (e.g., arabinose, galactose, and xylose) or ferulic acid are linked to the side chains [33]. Their structures vary significantly depending on the sources of POSs [34].

\subsection{Non-Carbohydrate Oligosaccharides}

Although carbohydrates are more likely to meet the criteria of prebiotics definition, there are some compounds that are not classified as carbohydrates but are recommended to be classified as prebiotics, such as cocoa-derived flavanols. In vivo and in vitro experiments demonstrate that flavanols can stimulate lactic acid bacteria [35].

\section{Production of Prebiotics}

Prebiotics play an important role in human health. They naturally exist in different dietary food products, including asparagus, sugar beet, garlic, chicory, onion, Jerusalem artichoke, wheat, honey, banana, barley, tomato, rye, soybean, human's and cow's milk, peas, beans, etc., and recently, seaweeds and microalgae [36]. Because of their low concentration in foods, they are manufactured on industrial large scales. Some of the prebiotics are produced by using lactose, sucrose, and starch as raw material $[37,38]$. Since most prebiotics are classified as GOS and FOS regarding industrial scale (Figure 1), there are many relevant studies on their production.

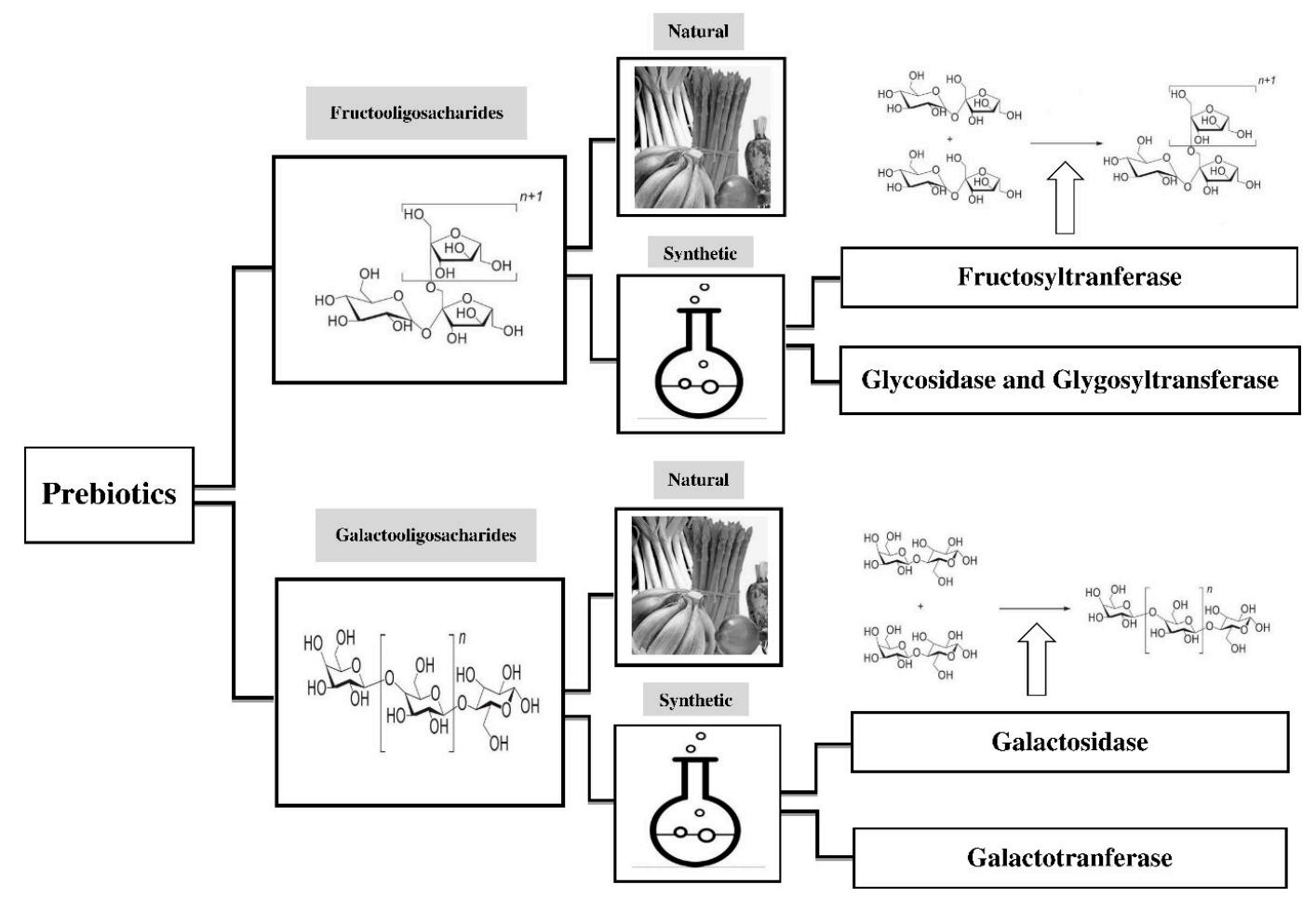

Figure 1. Sources and production of major prebiotics, including fructo-oligosaccharides (FOS) and galacto-oligosaccharides (GOS). Prebiotics exist in human diets in small concentration. Since they have crucial roles in health maintenance, they are manufactured on industrial large scales.

\subsection{FOS}

FOS exists in about 36,000 plants [39]; however, the concentration of FOS in these sources is not enough to have prebiotics effects. Therefore, FOS should be synthesized. There are various FOS production methods, which have been explained by several authors [40,41]. FOS can be synthesized chemically by using glycosidase and glycosyl-transferase [42]. The compounds that are used in these reactions are hazardous and costly, and the concentration of the end product (FOS) is very low. Thus, it cannot be produced on an industrial scale [43]. Fructosyl-transferase (FTase) is a key enzyme in 
producing FOS. FTase produces FOS from sucrose by transferring one to three molecules of fructose. Several microorganisms have FTase, such as Fusarium sp., Aspergillus sp., Aureobasidium sp., Penicillium sp., Arthrobacter sp., Zymomonas mobilis, Bacillus macerans, Candida, Kluyveromyces, and Saccharomyces cerevisiae [41,44-48]. Among these microorganisms, Aspergillus niger and Aureobasidium pullulans are mostly used in the industry [49].

For FOS production, the whole cell of a microorganism or free enzyme can be used $[40,45,50]$. There are different factors that can affect the concentration of produced FOS. The maximum amount of FOS produced by FTases depends on the initial concentration of sucrose (theoretically around $55-60 \%$ ). Glucose, which is a co-product of fermentation, inhibits trans-glycosylation [40,51]. Therefore, removing glucose and sucrose residues is a critical step to achieving higher yields of FOS fermentation. Some scientists claimed to utilize glucose oxidase and $\beta$-fructofuranosidase to enhance the yield of FOS production $[41,51,52]$. $\beta$-fructofuranosidase is capable of converting sucrose to FOS. The glucose produced during FOS fermentation is converted to gluconic acid by glucose oxidase. Unlike glucose, gluconic acid is able to be removed by ion-exchange resins or by coagulation with calcium carbonate $\left(\mathrm{CaCO}_{3}\right)$ [52]. Thus, the utilization of both enzymes increases the yield of FOS formation up to 98\% [53]. $\beta$-fructofuranosidase and glucose oxidase can be derived from Apostichopus japonicus and A. niger, respectively [54]. Glucose can be separated from FOS through nanofiltration methods. This process increases FOS production by up to $90 \%$ [55].

S. cerevisiae and Zymomonas mobilis are able to eliminate small saccharides, such as glucose, fructose, and sucrose, by converting saccharides to carbon dioxide and ethanol. S. cerevisiae cannot ferment oligosaccharides with four or more monosaccharide units. Sorbitol and FOS are also produced in small amounts during fermentation of sucrose by Z. mobilis [56-59].

\subsection{GOS}

GOSs were first chemically synthesized by nucleophilic and electrophilic displacement, but this method is currently deemed to be uneconomical at the industrial scale $[60,61]$. The key enzymes for GOS formation are galactosyl-transferase and galactosidase. Galactosyl-transferase is a stereoselective enzyme that can produce GOS in high quantities [61]. Nevertheless, the bio-catalysis of GOS via galactosyl-transferase is so costly, because this reaction needs nucleotide sugars as a donor. There are some approaches to decrease the cost of this reaction, such as globotriose production $[60,62]$ or using human milk oligosaccharides $[63,64]$.

Formation of GOS by means of galactosidase is much cheaper than galactosyl-transferases. However, galactosidase produces GOS in lower quantities, and this enzyme is less stereospecific than galactosyl-transferase. The amount of GOS produced by galactosidase can be improved in different ways: (i) increasing the concentration of donors and acceptors in the reaction, (ii) lowering water activity of the reaction, (iii) shifting the reaction equilibrium to the end product direction by the product elimination in the medium, and (iv) altering the synthesis conditions $[60,65]$.

$\beta$-Galactosidases come from different sources, such as Aspergillus oryzae, Sterigmatomyces elviae, Bifidobacteria, and Lactobacilli. Different sources of $\beta$-galactosidases cause various types of GOS that differ in the amount, DP, and glycosidic linkages [66-69]. Various sources of $\beta$-galactosidases need different conditions for optimizing GOS production. For example, fungal and bacterial, as well as yeast sources, require acidic and neutral $\mathrm{pH}$, respectively. Furthermore, high temperature necessitates for thermophilic sources. These conditions have been optimized in various studies [66,70-73].

For GOS bio-catalysis, the whole cell or just the free form of $\beta$-galactosidase can be used. The recombinant form of this enzyme is also available. The whole cell is exploited when the $\beta$-galactosidase isolation process is uneconomical [74]. The utilization of the whole cell is also much cheaper due to co-factors that naturally exist in the cell and cell membrane $[75,76]$, but it is not very crucial for GOS synthesis because $\beta$-galactosidase uses metal ions as co-factors.

There are some by-products, such as glucose and galactose, which do not have prebiotic effects and may decrease GOS synthesis yield. When the whole cell is used, these by-products can be removed by 
other metabolic processes. For instance, Sirobasidium magnum, S. elviae, and Rasopone minuta consume glucose as a carbon source when cultured on lactose medium for GOS synthesis [77-81]. As another example, galactose can induce the expression of $\beta$-galactosidase, and glucose is utilized as a carbon source in yeast cells [82]. However, some metabolic end products, including ethanol, lactic acid, and acetic acid, are produced, when viable whole cells are used, which can affect GOS production. Therefore, other methods are required to remove these metabolic products. Apart from the interference of metabolic end products with GOS production, the temperature is another unfavorable factor when using the whole cell. Temperature often increases the yield of GOS synthesis, which is undesirable and even fatal for non-thermophilic cells. In some studies, non-viable and resting cells are exploited. These kinds of cells do not have the drawbacks of viable cells, and their GOS production yields are much higher $[57,66,83]$.

Recombinant $\beta$-galactosidases have more advantages than native $\beta$-galactosidases, such as high production yield, easy purification, and improved enzyme stability, as well as an activity through molecular approaches [84]. Escherichia coli and Bacillus subtilis are mostly used for producing recombinant $\beta$-galactosidases. E. coli has some disadvantages, such as endotoxins production, difficulty in disulfide bonds expression, and acetate formation, which has toxic effects [85,86]. In contrast, the engineered B. subtilis does not produce any endo- or exo-toxins. But this bacterium has also some disadvantages, including producing proteases in high quantities (which are able to degrade proteins) and plasmid instability $[86,87]$.

Some yeasts, such as S. cerevisiae and Pichiapastoris, have been used for producing recombinant forms of $\beta$-galactosidase. Yeast has some advantages as compared to bacteria, including (i) higher range of productivity, (ii) disulfide bond production, and (iii) better protein folding [86,88,89].

\section{Prebiotics Mechanisms for Alteration of Gut Microbiota}

By the provision of energy sources for gut microbiota, prebiotics are able to modulate the composition and the function of these microorganisms [90]. Distant bacterial species in phylogeny share their skills to consume a specific prebiotic regularly [24]. It has also been recently reported by a functional metagenomics technique. In this method, genes from a human microbiota metagenomic library are identified for the breakdown of several prebiotics in a heterologous host, such as E. Coli [91]. Clones from various species, such as Actinobacteria, Bacteroidetes, and Firmicutes, can ferment FOS, GOS, and xylooligosaccharides (XOS). In contrast, some other studies report that specific species can degrade a given prebiotic. Fermentation of starch [92,93] and fructans [94] by Bifidobacterium sp. are examples in this regard. Another important factor for distinguishing species that are capable of fermenting a specific prebiotic is their chain length. For example, inulin (with DP of $\leq 60$ ) can be fermented only by a few species, whereas a large number of microorganisms are able to degrade FOS (with DP of $\leq 10)[26]$.

Sometimes, a by-product of a complex prebiotic's fermentation is a substrate for another microorganism, called cross-feeding [92,95]. For example, Ruminococcus bromii can degrade resistant starches, and several species can utilize the fermentation products of this reaction [31]. At the same time, some products may have antagonistic effects on other species.

Prebiotics are also able to modify the environment of the gut. As mentioned before, fermentation products of prebiotics are mostly acids, which decrease the gut $\mathrm{pH}$. It has been shown that one unit alteration in the gut $\mathrm{pH}$ from 6.5 to 5.5 can contribute to a change in the composition and population of the gut microbiota [96,97]. The $\mathrm{pH}$ alteration can change the population of acid-sensitive species, such as Bacteroids, and promote butyrate formation by Firmicutes. This process is called butyrogenic effect [96].

\section{Prebiotics Mechanisms for Health Maintenance and Protection against Disorders}

As it was mentioned earlier, the products of prebiotics degradation are mainly SCFAs. These molecules are small enough to diffuse through gut enterocytes and enter blood circulation. Therefore, 
prebiotics are able to affect not only the gastrointestinal track but also other distant site organs and systems [18] (Figure 2).

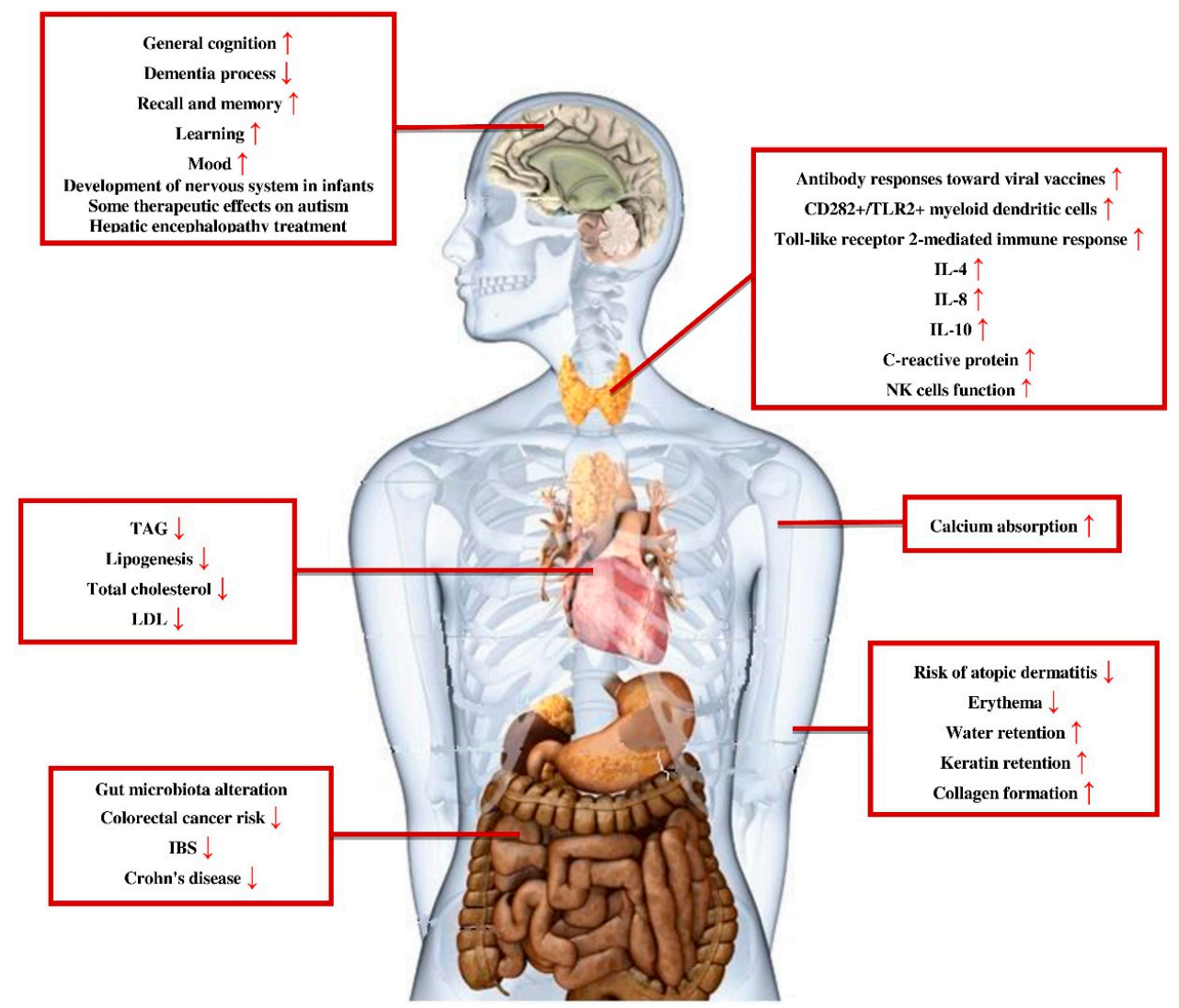

Figure 2. Prebiotics effects for health maintenance and protection against disorders. Prebiotics not only have protective effects on the gastrointestinal system but also on other parts of the body, such as the central nervous system, immune system, and cardiovascular system. TAG: triacylglycerol; LDL: low-density lipoprotein; IBS: irritable bowel syndrome; IL-4: interleukin 4; IL-8: interleukin 8; IL-10: interleukin 10; NK cells function: natural killer cells function.

\subsection{Prebiotics and Gastrointestinal Disorders}

\subsubsection{Irritable Bowel Syndrome and Crohn's Disease}

There are a few studies about the effects of prebiotics on irritable bowel syndrome (IBS) and Crohn's disease. IBS is a gastrointestinal syndrome characterized by chronic abdominal pain and altered bowel habits in the absence of any organic cause. Crohn's disease is a type of chronic, relapsing inflammatory bowel disease (IBD), which can involve any part of the gastrointestinal tract from the mouth to the anus. It has been reported that in both IBS and Crohn's disease, the Bifidobacteria and Faecalibacterium prausnitzii population along with Bacteroides to Firmicutes ratio were decreased [29,98].

A double-blind cross-over study demonstrated that the administration of oligofructose at the dose of $6 \mathrm{~g} /$ day for 4 weeks had no therapeutic effects on patients suffering from IBS [99]. Similarly, another randomized, double-blind, placebo-controlled trial published in 2000 implicated that $20 \mathrm{~g} /$ day FOS supplementation failed to improve IBS [100]. In contrast, two more recent randomized, double-blind, clinical trials have shown IBS symptoms improvement after consuming $5 \mathrm{~g} /$ day FOS for 6 weeks [101] or $3.5 \mathrm{~g} /$ day GOS for 12 weeks [102].

A group study in 2006 reported that supplementation with $15 \mathrm{~g} /$ day FOS for 3 weeks elevated Bifidobacteria population in the feces and improved Crohn's disease [103]. However, the other randomized, double-blind, and placebo-controlled trials demonstrated no clinical benefits 
after administrating $15 \mathrm{~g} /$ day FOS in patients with active Crohn's disease [104] and $20 \mathrm{~g} /$ day oligofructose-enriched inulin in patients with inactive or mild-to-moderately active Crohn's disease [105] for a duration of 4 weeks.

\subsubsection{Colorectal Cancer}

Colorectal cancer, ranked as the third most common malignancy worldwide, is a multi-step disease from genetic mutation to adenomatous polyps, which then leads to invasive and metastatic cancer [106]. It has been demonstrated that prebiotics fermentation products, such as butyrate, could have protective effects against the risk of colorectal cancer, as well as its progression, via inducing apoptosis [106-108]. In addition, a clinical trial demonstrated that symbiotic therapy (Lactobacillus rhamnosus and Bifidobacterium Lactis plus inulin) could reduce the risk of colorectal cancer by reducing the proliferation rate in colorectal, inducing colonic cells necrosis, which leads to improving the integrity and function of epithelial barrier [106,109,110].

\subsubsection{Necrotizing Enterocolitis}

Necrotizing enterocolitis (NEC) is a gastrointestinal emergency condition primarily in premature neonates, in which portions of the bowel undergo necrosis. It can lead to high morbidity and mortality rates [111]. Since prebiotics, such as FOS and GOS, can stimulate the growth of gut microbiota (e.g., Bifidobacteria) and reduce the pathogenic bacteria in preterm infants [112-114], it is claimed that they can prevent NEC [111]. Moreover, SCFAs can improve feeding tolerance by enhancing both gastric emptying and bowel motility [115-117]. A meta-analysis of four randomized controlled trials showed that FOS, GOS or their mixture could elevate the concentration of fecal Bifidobacteria, but had no significant effect on risk reduction and progression of NEC [118] (Table 1). Therefore, more clinical trials need to be done to elucidate the definite effects of prebiotics on NEC.

Table 1. Studies showing the effect of prebiotics on the gastrointestinal tract.

\begin{tabular}{|c|c|c|c|c|}
\hline Prebiotic & Dose & Subjects & Main Results & Reference \\
\hline \multirow{5}{*}{ FOS } & $6 \mathrm{~g} /$ day for 4 weeks & Patients with IBS & No therapeutic effect. & [99] \\
\hline & $20 \mathrm{~g} /$ day for 12 weeks & Patients with IBS & No therapeutic effect. & [100] \\
\hline & $5 \mathrm{~g} /$ day for 6 weeks & Patients with IBS & Improvement in IBS syndromes. & [102] \\
\hline & $15 \mathrm{~g} /$ day for 3 weeks & $\begin{array}{l}\text { Patients with active } \\
\text { ileocolonic Crohn's disease }\end{array}$ & Crohn's disease improvement. & [103] \\
\hline & $15 \mathrm{~g} /$ day for 4 weeks & Patients with Crohn's disease & $\begin{array}{l}\text { No clinical improvement in } \\
\text { Crohn's disease. }\end{array}$ & [104] \\
\hline GOS & $3.5 \mathrm{~g} /$ day for 12 weeks & Patients with IBS & Improvement in IBS syndromes. & [102] \\
\hline \multirow{2}{*}{$\begin{array}{l}\text { Mixture of FOS } \\
\text { and GOS }\end{array}$} & $\begin{array}{l}0.8 \mathrm{~g} / \mathrm{dL} \text { of a mixture of GOS } \\
\text { and FOS, ratio } 9: 1 \text { for } 30 \text { days }\end{array}$ & Healthy newborns & $\begin{array}{l}\text { Improvement in gastric } \\
\text { emptying and bowel motility. }\end{array}$ & [115] \\
\hline & $\begin{array}{l}0.8 \mathrm{~g} / \mathrm{dL} \text { of a mixture of GOS } \\
\text { and FOS, ratio } 9: 1 \text { for } 15 \text { days }\end{array}$ & Healthy newborns & $\begin{array}{l}\text { Improvement in gastric } \\
\text { emptying and bowel motility. }\end{array}$ & [116] \\
\hline \multirow{4}{*}{$\begin{array}{l}\text { Inulin-enriched } \\
\text { FOS }\end{array}$} & $20 \mathrm{~g} /$ day for 4 weeks & $\begin{array}{l}\text { Patients with inactive and } \\
\text { mild to moderately active } \\
\text { Crohn's disease }\end{array}$ & $\begin{array}{l}\text { No clinical Improvement in } \\
\text { Crohn's disease. }\end{array}$ & [105] \\
\hline & $\begin{array}{l}\text { Raftilose }^{\circledR} \text { Synergy } 1+ \\
\text { Bifidobacterium lactis Bb12, } \\
\text { Lactobacillus rhamnosus GG }\end{array}$ & HT29 or CaCo-2 cells & $\begin{array}{l}\text { Cell growth inhibition. As a } \\
\text { result, this mixture can decrease } \\
\text { the progression of colorectal } \\
\text { cancer. }\end{array}$ & [119] \\
\hline & Different doses & Rats with colon carcinogen & $\begin{array}{l}\text { Long-chain inulin effects are } \\
\text { dose-dependent on colorectal } \\
\text { cancer. }\end{array}$ & [120] \\
\hline & $\begin{array}{l}\text { Synergy } 1+\text { Bifidobacterium } \\
\text { lactis Bb12, Lactobacillus } \\
\text { rhamnosus GG }\end{array}$ & $\begin{array}{l}\text { Colon cancer patients and } \\
\text { polypectomized patients }\end{array}$ & $\begin{array}{l}\text { Decrease in the progression of } \\
\text { colorectal cancer. }\end{array}$ & [110] \\
\hline Lactose & $25 \mathrm{~g}$ daily for 15 days & Lactose malabsorbers & $\begin{array}{l}\text { Improvement in lactose } \\
\text { digestion. }\end{array}$ & [117] \\
\hline
\end{tabular}

FOS: Fructo-oligosaccharides; IBS: irritable bowel syndrome; and GOS: Galacto-oligosaccharides. 


\subsection{Prebiotics and the Immune System}

Consuming prebiotics can improve immunity functions by increasing the population of protective microorganisms. Animal and human studies have shown that prebiotics can decrease the population of harmful bacteria by Lactobacilli and Bifidobacteria [12,121-124]. For example, mannose can reduce colonization of pathogens by promoting mannose adhesion to Salmonella. Mannose binds to Salmonella via type 1 fimbriae (finger-like projections) [125]. In addition, pathogens are not able to bind to the epithelium in the presence of OSCs. Prebiotics can also induce the expression of immunity molecules, especially cytokines (Table 2).

Interestingly, maternal prebiotics metabolites are able to cross the placenta and can affect the development of the fetal immune system [12,126]. In 2010, Fugiwara et al. [127] reported that FOS administration in a pregnant mouse model modified offspring microbiota, and consequently, their skin inflammation was attenuated. In contrast, Shadid et al. [128] in a placebo-controlled, randomized, and double-blinded study demonstrated that bifidogenic effects of prebiotics supplementation in humans could not be transferred to the next generation. The details of well-known prebiotic effects on the immune systems are discussed below:

I- Oligofructose and inulin mixture: The mixture of oligofructans and inulin can improve antibody responses toward viral vaccines, such as influenza and measles [129].

II- FOS: Studies have shown the improvement of antibody response to influenza vaccine following FOS consumption. Moreover, the side effects of the influenza vaccine are reduced $[130,131]$. Diarrhea-associated fever in infants is also reduced by this category of prebiotics. Apart from these, it can decrease the use of antibiotics, duration of disease, and the incidence of febrile seizures in infants [132,133]. $\beta(2 \rightarrow 1)$ fructans can up-regulate the level of interleukin 4 (IL-4) in serum, CD282+/TLR2+ myeloid dendritic cells, and a toll-like receptor 2-mediated immune response in healthy volunteers [134]. In contrast, another study demonstrated that the salivary immunoglobulin A ( $\operatorname{IgA})$, immune cells in serum, and activation and proliferation of $\mathrm{T}$ cells and natural killer (NK) cells were not changed after consuming $\beta(2 \rightarrow 1)$ fructans [135]. It has been noted that FOS reduces the risk of some immune diseases in infants, such as atopic dermatitis $[136,137]$. This type of prebiotic decreases the expression of IL-6 and phagocytosis in monocytes and granulocytes [138].

III- GOS: Studies showed that GOS increased the blood level of interleukin 8 (IL-8), interleukin 10 (IL-10), and C-reactive protein in adults, but decreased IL-1 $\beta$. It has been found that the function of NK cells improves by consuming GOS $[139,140]$. In infants, GOS reduces the risk of atopic dermatitis and eczema $[136,137,141]$.

IV- AOS (acidic oligosaccharides): The possibility of atopic dermatitis is reduced by AOS in low-risk infants [136]. 
Table 2. Studies showing the effect of prebiotics on the immune system.

\begin{tabular}{|c|c|c|c|c|}
\hline Prebiotic & Dose & Subjects & Main Results & Reference \\
\hline \multirow{7}{*}{ FOS } & $\begin{array}{l}8 \mathrm{oz} / \text { day of an experimental formula containing } \\
\text { FOS for } 183 \text { days }\end{array}$ & Adults aged 65 and older & $\begin{array}{l}\text { Antibody responses toward viral vaccines } \\
\text { improved. } \\
\text { Hospitalization due to influenza and side } \\
\text { effects of influenza vaccines decreased. }\end{array}$ & [130] \\
\hline & $8 \mathrm{~g} /$ day Orafti ${ }^{\circledR}$ Synergy1 for 8 weeks & Adults aged $45-63$ years & $\begin{array}{l}\text { Immune responses toward influenza vaccines } \\
\text { improved. }\end{array}$ & [135] \\
\hline & $0.55 \mathrm{~g}$ FOS per $15 \mathrm{~g}$ of cereal for 6 months & $\begin{array}{l}\text { Non-breast-feeding infants aged } \\
4-24 \text { months }\end{array}$ & $\begin{array}{l}\text { Diarrhea associated fever, febrile seizure } \\
\text { incident, antibiotics usage, and duration of } \\
\text { infectious disease decreased. }\end{array}$ & [133] \\
\hline & $\begin{array}{l}3 \times 5 \mathrm{~g} / \text { day FOS consisted of two } 28 \text { day } \\
\text { treatments separated by a } 14 \text {-day washout }\end{array}$ & Healthy volunteers & $\begin{array}{l}\text { IL-4 in serum, CD282+/TLR2+ myeloid } \\
\text { dendritic cells, and toll-like receptor } \\
\text { 2-mediated immune response were } \\
\text { up-regulated. }\end{array}$ & [134] \\
\hline & Not exactly defined & Infants & $\begin{array}{l}\text { Risk of some immune diseases, such as atopic } \\
\text { dermatitis, reduced. }\end{array}$ & {$[136,137]$} \\
\hline & $2 \times 4 \mathrm{~g} /$ day for 3 weeks & Elderly nursing home patients & $\begin{array}{l}\text { IL-6 expression and phagocytosis in monocytes } \\
\text { and granulocytes decreased. }\end{array}$ & [138] \\
\hline & $8 \mathrm{~g} /$ day Orafti ${ }^{\circledR}$ Synergy1 for 4 weeks & Adults aged $45-65$ years & $\begin{array}{l}\text { Salivary IgA, immune cells in serum, } \\
\text { activation, and proliferation of T and NK cell } \\
\text { not changed. }\end{array}$ & [131] \\
\hline \multirow{5}{*}{ GOS } & $5.5 \mathrm{~g} /$ day for 10 weeks & Elderly subjects & $\begin{array}{l}\text { Phagocytosis, NK cell activity, and IL-10 (an } \\
\text { anti-inflammatory cytokine) level increased. } \\
\text { Pro-inflammatory cytokines, such as IL-6, } \\
\text { IL-1 } \beta \text {, and tumor necrosis factor- } \alpha \text {, levels } \\
\text { decreased. }\end{array}$ & [139] \\
\hline & $\begin{array}{l}5.5 \mathrm{~g} / \text { day consisted of two } 10 \text { weeks of treatment } \\
\text { separated by } 4 \text { weeks of washout }\end{array}$ & Elderly subjects & $\begin{array}{l}\text { IL-10, IL-8, C-reactive protein, and NK cell } \\
\text { activity elevated. } \\
\text { IL-1 } \beta \text { level decreased. }\end{array}$ & [140] \\
\hline & Not exactly defined & Infants & \multirow{3}{*}{$\begin{array}{l}\text { Risk of some immune diseases, such as atopic } \\
\text { dermatitis, reduced. }\end{array}$} & [136] \\
\hline & $0.8 \mathrm{~g} / 100 \mathrm{~mL}$ & Infants & & [137] \\
\hline & $0.8 \mathrm{~g} /$ day for 6 months & Newborn infants & & [141] \\
\hline AOS & Not exactly defined & Infants & Atopic dermatitis in low-risk infants reduced. & [136] \\
\hline $\begin{array}{l}\text { Oligofructose and inulin } \\
\text { mixture }\end{array}$ & $\begin{array}{l}\text { Oligofructose }(70 \%) \text { and inulin }(30 \%) \text { with a } \\
\text { concentration of } 1 \mathrm{~g} \text { per } 25 \mathrm{~g} \text { of dry weight cereal } \\
\text { during } 4 \text { weeks prior to measles vaccination }\end{array}$ & Infants aged 7-9 months & $\begin{array}{l}\text { Antibody responses toward viral vaccines } \\
\text { improved. }\end{array}$ & [129] \\
\hline
\end{tabular}

FOS: Fructo-oligosaccharides; IBS: irritable bowel syndrome; GOS: Galacto-oligosaccharides; AOS: acidic oligosaccharides; NK cell: natural killer cell; IL-4: interleukin 4; IL-10: interleukin 10, IL-8: interleukin 8; and IL-6: interleukin 6. 


\subsection{Prebiotics and the Nervous System}

The gastrointestinal tract is connected to the central nervous system through the "gut-brain axis" [142]. For instance, administration of prebiotics in piglets decreases the gray matter in order to improve neural pruning [143]. But the regulatory effects of prebiotics on the human brain have not been completely defined. Gut microbiota affects the brain through three routes, including neural, endocrine, and immune pathways [142,144,145].

I- Neural Pathway: The products of prebiotics fermentation can affect the brain by the vagus nerve [146]. Some prebiotics, such as FOS and GOS, have regulatory effects on brain-derived neurotrophic factors, neurotransmitters (e.g., d-serine), and synaptic proteins (e.g., synaptophysin and N-methyl-D-aspartate or NMDA receptor subunits) $[147,148]$.

II- Endocrine Pathway: Hypothalamic-pituitary-adrenal axis is a neuroendocrine pathway. The microbiome growth in mice can induce corticosterone and adrenocorticotropic hormone in an appropriate way [149]. In addition, prebiotics act as a regulator of other hormones, such as plasma peptide YY [147].

III- Immune Pathway: As discussed before, prebiotics can affect different aspects of the immune system. Beside neurological functions, prebiotics are also capable of influencing mood, memory, learning, and some psychiatry disorders by changing the activity and/or composition of gut microbiota [145] (Table 3).

$I V$ - Mood: Stress hormones are able to affect anxiety-related behaviors [150,151]. It was demonstrated that the level of stress hormones (adrenocorticotropic hormone (ACTH) and corticosterone) increased in germ-free mice following exposure to controlled stress. After administrating Bifidobacterium infantis, corticosterone and ACTH reached normal levels [149].

$V-\quad M e m o r y$, concentration, and learning: Recently, a number of studies have shown the relation between memory and administration of fermentable compounds in both animals and humans [152]. Investigations on a different kind of prebiotics have implicated memory improvement in middle-aged adults [153,154]. Some prebiotics, such as arabinoxylan and arabinose, can enhance general cognition and attenuate the accumulation process of dementia-related glial fibrillary acidic protein in mice [155]. Prebiotics may be more efficient in preserving recall and learning rather than the development process. In 2015, a randomized, double-blind, and placebo-controlled study was performed to examine the effects of FOS and GOS daily consumption for three weeks on the level of salivary cortisol and emotional alteration regarding this hormone. FOS had no significant effect, but $5.5 \mathrm{~g}$ GOS intake increased the level of cortisol in saliva and enhanced the concentration in adults [156]. A randomized, double-blind, placebo-controlled trial demonstrated that administration of non-starch polysaccharides ( $3.6 \mathrm{~g}$ per day) for twelve weeks enhanced recall and memory processes in the middle-aged adult $[153,154]$. In contrast, the mixture of FOS, GOS, and AOS could not enhance the development of the nervous system in preterm infants after 24 months [157]. In two other clinical investigations, Smith et al. observed that administration of inulin-enriched oligofructose might enhance mood, recognition, immediate memory, and recall (after 4 hours). However, this prebiotic failed to recover long-term memory (after 43 days) $[158,159]$. In another study, administration of polydextrose and GOS mixture decreased anxiety-like behavior in male piglets and promoted positive social interactions in rats $[143,160]$. Furthermore, the consumption of this mixture boosted their cognition memory [160,161].

VI- Autism: 70\% of people with autism are suffering from concomitant gastrointestinal disorders compared to $9 \%$ of healthy individuals. Chronic constipation (and other diseases as a result of constipation), abdominal pain with or without diarrhea, gastroesophageal reflux disease, abdominal bloating, disaccharide deficiencies, gastrointestinal tract inflammation, and enteric nervous system abnormalities are examples of gastrointestinal symptoms and signs that are reported for patients with autism spectrum disorders [162]. The severity of autism is shown to be correlated to higher gastrointestinal disorders [163]. Interestingly, a review article published in 
2016 confirmed these statements [164]. The composition of gut microbiota is changed in patients with autism disorders. Some studies have shown high levels of Clostridium and depleted Bifidobacterium in feces. In children with autism, gut metabolites are different from healthy individuals. For example, the amount of SCFAs in children with autism is lower than healthy ones [163,165]. Various prebiotics, such as wheat fiber, may have therapeutic effects on patients with autism by decreasing the population of Clostridium perfringens and increasing the rate of Bifidobacteria [166]. Catecholamines, which are a category of neurotransmitters, are increased in individuals with autism. These neurotransmitters are produced by tyrosine hydroxylase. An in vitro study in a rat adrenal medulla cell line demonstrated that SCFAs, the products of prebiotic fermentation, could induce the expression of tyrosine hydroxylase [167]. However, further investigations are required to understand which prebiotics have therapeutic effects on human autism.

VII- Hepatic encephalopathy: Hepatic encephalopathy happens when the liver does not function properly. The main reason for hepatic encephalopathy is the increases in the level of blood ammonia. This condition causes numerous psychiatric and neurologic complications, including personality, speech, and movement disorders, as well as cognition impairment, and may eventually result in coma and death. In 1966, it was demonstrated that lactulose could effectively treat hepatic encephalopathy by decreasing the level of ammonia in the gut. Lactulose can improve the life quality of people suffering from hepatic encephalopathy. This prebiotic also has preventive effects on hepatic encephalopathy $[143,168-170]$. Lactulose exerts its beneficial effects on hepatic encephalopathy through different pathways. First, the product of lactulose fermentation is lactic acid, which is able to reduce the colonic lumen $\mathrm{pH}$ by releasing $\mathrm{H}^{+}$. The ammonia in the gut reacts with proton and produces ammonium. This conversion develops a concentration gradient that increases the amount of ammonia reuptake from the blood into the gastrointestinal tract [171]. Second, in the presence of lactulose in the gastrointestinal tract, the bacteria utilize the energy of lactulose fermentation instead of the conversion of amino acids to ammonia energy. Third, lactulose can inhibit glutaminase and prevent the production of ammonia from glutamine [143]. Finally, lactulose shortens the colonic transit time. Thus, it can reduce the level of ammonia in the gastrointestinal tract. Other compounds, such as lactitol, may also be as effective as lactulose in the treatment of hepatic encephalopathy. Interestingly, the side effects of lactitol are much fewer than lactulose (e.g., flatulence and nausea) [172-174]. 
Table 3. Studies showing the effect of prebiotics on the nervous system.

\begin{tabular}{|c|c|c|c|c|}
\hline Prebiotic & Dose & Subjects & Main Results & Reference \\
\hline \multirow{2}{*}{ Non-starch polysaccharides (NSPs) } & $4 \mathrm{~g}$ of NSPs $\left(\right.$ Ambrotose $\left.^{\circledR}\right)$ & Middle-aged healthy adults & $\begin{array}{l}\text { Recognition and working memory } \\
\text { performance improved. }\end{array}$ & [153] \\
\hline & $3.6 \mathrm{~g} /$ day for 12 weeks & Middle-aged healthy adults & Cognitive function and well-being optimized. & [154] \\
\hline Mixture of FOS, GOS, and AOS & $\begin{array}{l}\text { Supplementation between day } 3 \text { and } 30 \text { of life, and } \\
\text { the results measured during } 24 \text { months }\end{array}$ & Preterm infants & $\begin{array}{l}\text { Neurodevelopment did not improve } \\
\text { significantly. }\end{array}$ & [157] \\
\hline \multirow{2}{*}{ Inulin-enriched oligofructose } & $5 \mathrm{~g}$, the results measured after $4 \mathrm{~h}$ & $19-30$ years old healthy individuals & $\begin{array}{l}\text { Mood, recognition, immediate memory, and } \\
\text { recall enhanced. }\end{array}$ & [158] \\
\hline & $\begin{array}{l}10 \mathrm{~g} / \text { day of Synergy }{ }^{\circledR} 1 \text {, the results measured after } \\
43 \text { days }\end{array}$ & 19-64 years old healthy individuals & $\begin{array}{l}\text { Long-term memory did not change } \\
\text { significantly. }\end{array}$ & [159] \\
\hline \multirow{3}{*}{ Mixture of GOS and polydextrose } & 2.4 and $7 \mathrm{~g} / \mathrm{L}$ of polydextrose and GOS & Male piglets & $\begin{array}{l}\text { They may have neurodevelopment effect in } \\
\text { human infants. }\end{array}$ & [143] \\
\hline & $7 \mathrm{~g} / \mathrm{kg}$ prebiotics mixture & Rats & \multirow{2}{*}{$\begin{array}{l}\text { Memory and social behaviors improved, and } \\
\text { anxiety-like behaviors reduced. }\end{array}$} & \multirow{2}{*}{ [160] } \\
\hline & $15 \mathrm{~g} / \mathrm{kg}$ prebiotics mixture & Mice & & \\
\hline \multirow[t]{2}{*}{$\begin{array}{l}\text { Water extract of Triticum aestivum } \\
\text { composed of arabinoxylan, } \beta \text {-glucan, } \\
\text { and arabinose }\end{array}$} & - & Rats & $\begin{array}{l}\text { Arabinoxylan, } \beta \text {-glucan, and arabinose had } \\
\text { preserved cognition effects against vascular } \\
\text { dementia. }\end{array}$ & [155] \\
\hline & $5.5 \mathrm{~g} /$ day for 3 weeks & $18-45$ years old healthy volunteers & $\begin{array}{l}\text { Salivary cortisol awakening response was } \\
\text { decreased, attentional vigilance to negative } \\
\text { versus positive information reduced, and the } \\
\text { concentration improved. }\end{array}$ & [156] \\
\hline \multirow{5}{*}{ Lactulose } & $\begin{array}{l}\text { Lactoferrin }(0.6 \mathrm{~g} / \mathrm{L}) \text { and Milk fat globule } \\
\text { membrane }(\mathrm{MFGM})(5.0 \mathrm{~g} / \mathrm{L})\end{array}$ & Male piglets & $\begin{array}{l}\text { Lactulose appeared to have neurodevelopment } \\
\text { effect in human infants. }\end{array}$ & [143] \\
\hline & Duphalac ${ }^{\circledR} 90-150 \mathrm{~mL} / \mathrm{d}$ & $\begin{array}{l}\text { Patients with chronic portal-systemic } \\
\text { encephalopathy (PSE) }\end{array}$ & Blood ammonia levels decreased. & [168] \\
\hline & $\begin{array}{l}30-60 \mathrm{~mL} \text { of lactulose in } 2 \text { or } 3 \text { divided doses for } \\
3 \text { months }\end{array}$ & Patients with cirrhosis & $\begin{array}{l}\text { Cognitive function and health-related quality } \\
\text { of life improved. }\end{array}$ & [169] \\
\hline & Meta-analysis & $\begin{array}{l}\text { Patients with subclinical hepatic } \\
\text { encephalopathy }\end{array}$ & $\begin{array}{l}\text { Lactulose had the most beneficial influence } \\
\text { among prebiotics and probiotics. }\end{array}$ & {$[170]$} \\
\hline & $67 \mathrm{mg} /$ day for long-term therapy (1 to 10 months) & Patients with chronic PSE & $\begin{array}{l}\text { The lower intestinal tract was acidified, and } \\
\text { lactulose had a beneficial effect on chronic PSE. }\end{array}$ & [171] \\
\hline
\end{tabular}

NSPs: non-starch polysaccharides; FOS: Fructo-oligosaccharides; GOS: Galacto-oligosaccharides; and AOS: acidic oligosaccharides. 


\subsection{Prebiotics and Skin}

As mentioned in the previous sections, the consumption of prebiotics was shown to decrease the risk of development, as well as the severity of allergic skin diseases, such as atopic dermatitis [136,137]. In hairless mice exposed to the UV, the consumption of GOS for 12 weeks enhanced water retention and also prevented the development of erythema [175]. On the other hand, GOS can improve skin barrier by increasing dermal expression of cell adhesion and matrix formation markers (e.g., CD44 and collagen type 1). Upon metabolizing aromatic amino acids by gut microbes, some compounds, such as phenols, may be produced. These compounds are transferred into the skin. Phenols, such as p-cresol, may be toxic for patients with underlying kidney diseases [176]. In women, consumption of GOS with or without probiotics, such as Bifidobacterium breve, can abolish the reduction of water and keratin caused by phenols [177-180] (Table 4).

Table 4. Studies showing the effect of prebiotics on the skin.

\begin{tabular}{|c|c|c|c|c|}
\hline Prebiotic & Dose & Subjects & Main Results & Reference \\
\hline AOS & Not exactly defined & Infants & $\begin{array}{l}\text { Formula supplementation } \\
\text { with a specific mixture of } \\
\text { oligosaccharides was effective } \\
\text { in preventing atopic } \\
\text { dermatitis in low-risk infants. }\end{array}$ & [136] \\
\hline GOS & $\begin{array}{l}\text { Not exactly defined } \\
0.8 \mathrm{~g} / 100 \mathrm{~mL} \\
0.8 \mathrm{~g} / \text { day for } 6 \text { months }\end{array}$ & $\begin{array}{l}\text { Infants } \\
\text { Infants } \\
\text { Newborn infants }\end{array}$ & $\begin{array}{l}\text { Risk of some immune diseases, } \\
\text { such as atopic dermatitis, } \\
\text { reduced. }\end{array}$ & $\begin{array}{l}{[136]} \\
{[137]} \\
{[141]}\end{array}$ \\
\hline \multirow{2}{*}{$\begin{array}{l}\text { GOS with or } \\
\text { without probiotics }\end{array}$} & $\begin{array}{l}100 \text { mg of GOS daily for } \\
12 \text { weeks }\end{array}$ & $\begin{array}{l}\text { Hairless mice exposed to } \\
\text { the UV }\end{array}$ & $\begin{array}{l}\text { Water retention enhanced, and } \\
\text { erythema reduced. }\end{array}$ & [175] \\
\hline & $600 \mathrm{mg}$ of GOS for 4 weeks & Adult healthy women & $\begin{array}{l}\text { Water and keratin reduction } \\
\text { caused by phenols decreased. }\end{array}$ & [177] \\
\hline
\end{tabular}

\subsection{Prebiotics and Cardiovascular System}

According to the statistics, 30\% of the deaths in the United States in 2013 were caused by cardiovascular diseases (CVD). The main reason for this growing trend is the alteration of people's lifestyles and eating habits [181]. Therefore, many researchers have studied the influence of fibers and prebiotics consumption on CVD. However, the direct beneficial functions of prebiotics in this regard have not been demonstrated yet. In this section, we summarized some of the indirect effects of prebiotics on CVD.

Prebiotics are able to lower the risk of CVD by reducing the inflammatory elements. Several investigations demonstrated an improvement in the lipid profile by consuming prebiotics. In a randomized, double-blind, and placebo-controlled crossover clinical trial, Letexier et al. [182] treated healthy individuals with $10 \mathrm{~g}$ /day inulin for three weeks. They observed that this regimen decreased blood triacylglycerol (TAG) and liver lipogenesis, but it had no statistically significant effect on the cholesterol level.

In line with these findings, in a randomized and double-blinded cross-over trial, Russo et al. [183] demonstrated that the consumption of inulin-enriched pasta with a formulation of $86 \%$ semolina, 11\% inulin, and 3\% durum wheat vital gluten decreased both TAG and lipogenesis in healthy individuals, rather than cholesterol level. In contrast, Frochen and Beylot [184] reported that the consumption of $10 \mathrm{~g} /$ day inulin-type fructans for six months had no significant effects on lipogenesis in the liver of healthy subjects.

To assess the effects of oral L-rhamnose and lactulose on lipid profile in a partially randomized crossover study, Vogt et al. [185] administered $25 \mathrm{~g} /$ day of these two prebiotics for four weeks in healthy individuals. They observed a significant reduction in the synthesis and level of TAG but not cholesterol. Opposed to that, the results of another investigation in 1991 suggested that lactulose increased blood cholesterol (up to 10\%) and B-apolipoprotein (up to 19\%) [186].

In a double-blind, randomized, placebo-controlled, crossover study on overweight subjects with $\geq 3$ risk factors of metabolic syndrome, Bimuno ${ }^{\circledR}$ Galacto-oligosaccharides (B-GOS) administration for 
12 weeks decreased circulating cholesterol, TAG, and total:HDL (high-density lipoprotein) cholesterol ratio [187]. However, in the elderly, this prebiotic had no significant effect on the total:HDL cholesterol ratio [139]. The effect of $\beta$-glucan intake on lipid profile was measured in a meta-analysis study (from 1990 through Dec. 2009). It was implicated that $\beta$-glucan consumption could reduce the level of total cholesterol and LDL [188]. Finally, a meta-analysis of relevant randomized controlled clinical trials published between 1995 and 2005 implicated that FOS could reduce TAG level with an average rate of 7.5\% [189].

Paradoxically, prebiotics may have a detrimental effect on lipid profile through producing some SCFAs, such as acetate. Acetate can be converted to acetyl-CoA, which is a substrate to synthesize fatty acids in hepatocytes [190]. This can justify the increase in the blood concentration of cholesterol and triglycerides after rectal infusion of acetate [191]. However, some other SCFAs, such as propionate and butyrate, may improve lipid profile. Propionate can inhibit lipid synthesis from acetate [192]. Therefore, prebiotics, such as FOS and L-rhamnose, may have lipogenic effects by producing acetate, butyrate, and propionate [14,193]. Hence, it is crucial to determine the end products of prebiotics to select the appropriate one for this purpose. Although prebiotics are claimed to be beneficial for obesity-related diseases, such as fatty liver disease, particularly, non-alcoholic fatty liver issue in one study [194], there is at least another clinical trial that refuted this opinion [195] (Table 5).

Table 5. Studies showing the effect of prebiotics on the cardiovascular system.

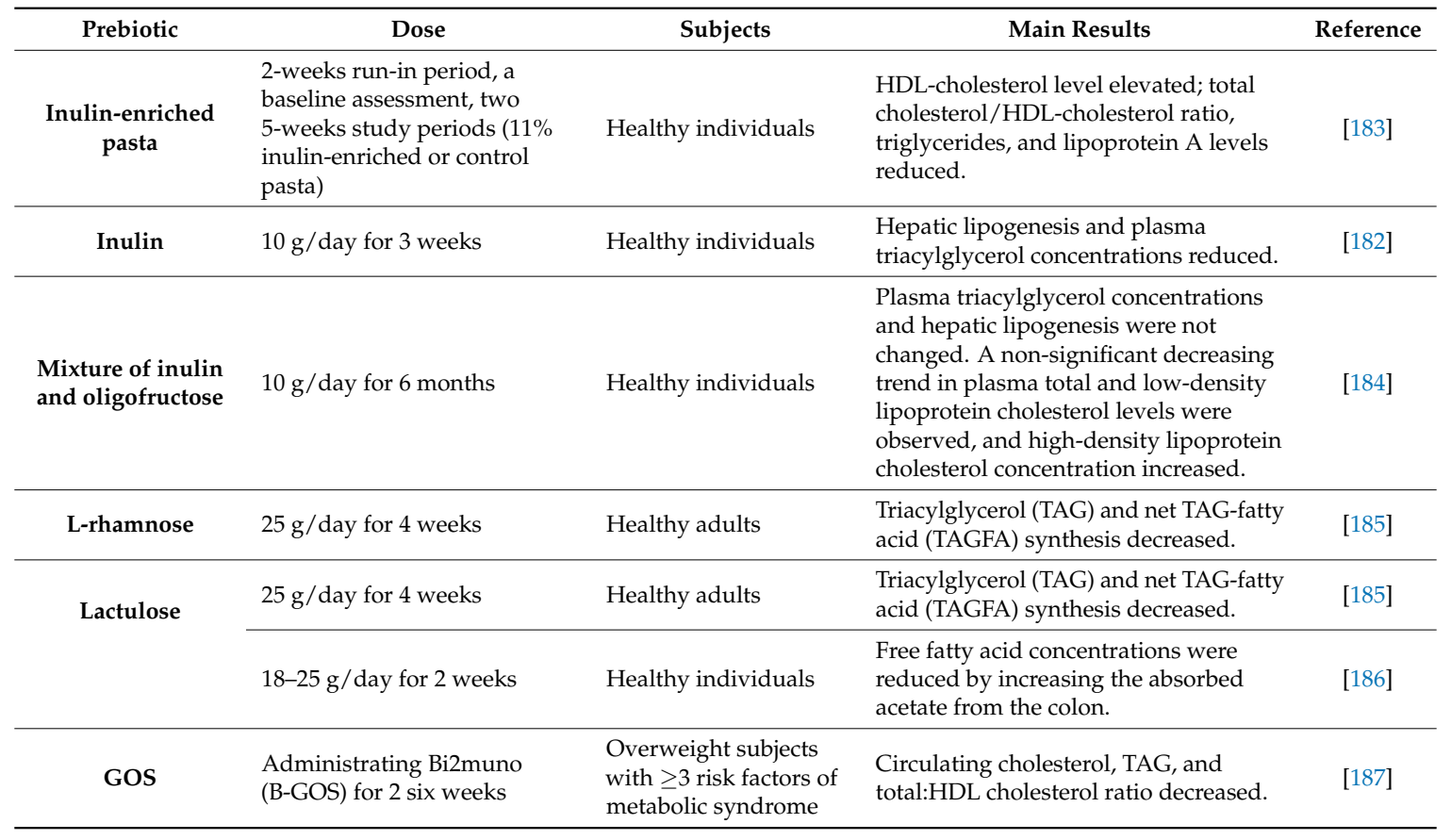

\subsection{Prebiotics and Calcium Absorption}

Statistics have shown that more than 28 million people in the United States have osteoporosis or low bone mass, and in European Union, one out of eight citizens over 50 years old have spinal fracture each year [196]. There are clinical trials on the impact of prebiotics dietary fibers on the absorption of minerals, such as calcium, but the results are conflicting. Some studies have shown that consumption of lactulose, TOS or inulin + oligofructose in doses ranged between 5 to $20 \mathrm{~g} /$ day significantly absorb calcium absorption. In contrast, such a phenomenon is not observed for GOS or FOS (Table 6) [197]. 
Table 6. Studies showing the effect of prebiotics on mineral absorption.

\begin{tabular}{|c|c|c|c|c|}
\hline Prebiotic & Dose & Subjects & Main Results & Reference \\
\hline Inulin or oligofructose & $\begin{array}{l}17 \mathrm{~g} \text { of inulin or oligofructose } \\
\text { and } 7 \mathrm{~g} \text { for three experimental } \\
\text { periods of three days each. }\end{array}$ & $\begin{array}{l}\text { Patients with } \\
\text { conventional ileostomy } \\
\text { because of ulcerative } \\
\text { colitis }\end{array}$ & $\begin{array}{l}\text { No significant effect on } \\
\text { calcium, magnesium, zinc, } \\
\text { and iron absorption. }\end{array}$ & [198] \\
\hline FOS or GOS & $15 \mathrm{~g} /$ day for 3 weeks & $\begin{array}{l}\text { Healthy, nonanemic, } \\
\text { male }\end{array}$ & $\begin{array}{l}\text { No significant effect on } \\
\text { calcium and iron } \\
\text { absorption. }\end{array}$ & [199] \\
\hline FOS enriched milk & $5 \mathrm{~g}$ FOS/L with light breakfast & Healthy adults & $\begin{array}{l}\text { No significant effect on } \\
\text { calcium absorption. }\end{array}$ & [201] \\
\hline Lactulose & $\begin{array}{l}5 \text { or } 10 \text { g per day for two } 9 \\
\text { days with 19-day washout in } \\
\text { between }\end{array}$ & $\begin{array}{l}\text { Post-menopausal } \\
\text { women }\end{array}$ & $\begin{array}{l}\text { Calcium absorption } \\
\text { increased in a } \\
\text { dose-response way. }\end{array}$ & [202] \\
\hline $\begin{array}{l}\text { A mixed short and long } \\
\text { degree of polymerized } \\
\text { inulin-type fructan product }\end{array}$ & $8 \mathrm{~g} /$ day for 8 weeks or 1 year & & $\begin{array}{l}\text { Calcium absorption } \\
\text { increased significantly. }\end{array}$ & [204] \\
\hline $\begin{array}{l}\text { The mixture of inulin + } \\
\text { oligofructose }\end{array}$ & $\begin{array}{l}8 \mathrm{~g} / \text { day for two } 3 \text { weeks, } \\
\text { separated by a 2-week } \\
\text { washout period }\end{array}$ & $\begin{array}{l}\text { Girls at or near } \\
\text { menarche. }\end{array}$ & $\begin{array}{l}\text { Calcium absorption } \\
\text { increased. }\end{array}$ & [205] \\
\hline
\end{tabular}

\section{Prebiotics Safety}

Prebiotics are assumed to lack life-threatening or severe side effects. Intestinal enzymes cannot break down oligosaccharides and polysaccharides. They are transported to the colon to be fermented by the gut microbiota. Therefore, the side effects of prebiotics are mostly the result of their osmotic functions. In this regard, osmotic diarrhea, bloating, cramping, and flatulence could be experienced in prebiotic recipients. The prebiotics chain length is an influential parameter for the development of their side effects. Interestingly, prebiotics with shorter chain length may have more side effects. The possible explanation for this phenomenon is that shorter inulin molecules are metabolized primarily in the proximal colon and are more rapidly fermented; whereas, longer chain ones are fermented later and slower in the distal colon. Beside chain length, the prebiotic dose can affect its safety profile. For example, low (2.5-10 g/day) and high (40-50 g/day) doses of prebiotics can cause flatulence and osmotic diarrhea, respectively. Noting that, a daily dose of $2.5-10 \mathrm{~g}$ prebiotics is required to exert their beneficial functions on human health. This means that prebiotics within their therapeutic doses can cause mild to moderate side effects. Most products of prebiotics in the market have doses of $1.5-5 \mathrm{~g}$ per portion [206].

As potential alternatives or adjunctive therapies (synbiotics) to probiotics [207], prebiotics may have similar safety concerns. The major safety issue of probiotics includes the risk of bacteremia, sepsis or endocarditis, especially in patients with prominent immuno-deficiency (e.g., HIV, cancer, transplant), severe malnutrition or incompetent intestinal epithelial barrier (e.g., severe diarrhea, NEC) [208]. It is noteworthy that these potential complications have not been considered or at least reported in relevant clinical studies exclusively for prebiotics.

\section{Conclusions}

Prebiotics exert a remarkable influence on human health, which makes them alluring attractive agents to improve the quality of human life against cancer, vascular diseases, obesity, and mental disorders. There are many studies on the positive effects of prebiotics on human health; however, accurately designed long-term clinical trials and genomics investigations are needed to confirm the health claims.

By determining the fundamental mechanisms of prebiotics, scientists would be able to formulate enhanced food supplements to ameliorate human health. The ability to normalize the composition of 
the gut microbiota by prebiotic dietary substances is an appealing procedure in the control and healing of some foremost disorders. In other words, the gut microbiota, as a major body organ, can be fed properly with prebiotics to become stronger and healthier, which, in turn, can impact the overall health.

Considering the diversity of the gut microbiota in various populations and countries, and even in different individuals, based on the variety of dietary regimens, developing effective and diverse probiotics for the modification of the microbiota hemostasis seems not to be very feasible. On the other hand, prebiotics seem to be a more convenient option in this regard, especially due to a much easier production and formulation process, as well as lack of need for cold chain in transportation and storage. The negligible side effects of prebiotics are also an important advantage.

Therefore, designing particular, population-specific prebiotics with regard to the resident gut microbiota specific to each community may ultimately contribute to the reduction of certain disorders in each society as a standardized approach. This concept provides the potential to stop the huge prebiotic controversies and can be recommended in future guidelines from the $\mathrm{FAO}$ and/or the WHO on prebiotics.

Author Contributions: All authors have contributed to the manuscript preparation, review, and editing. Funding: This study was supported by a Grant from Shiraz University of Medical Sciences, Shiraz, Iran.

Conflicts of Interest: The authors declare no conflict of interest.

\section{References}

1. Collins, S.; Reid, G. Distant site effects of ingested prebiotics. Nutrients 2016, 8, 523. [CrossRef]

2. Louis, P.; Flint, H.J.; Michel, C. How to manipulate the microbiota: Prebiotics. In Microbiota of the Human Body; Springer: Basel, Switzerland, 2016; pp. 119-142.

3. Walker, A.W.; Ince, J.; Duncan, S.H.; Webster, L.M.; Holtrop, G.; Ze, X.; Brown, D.; Stares, M.D.; Scott, P.; Bergerat, A. Dominant and diet-responsive groups of bacteria within the human colonic microbiota. ISME J. 2011, 5, 220-230. [CrossRef]

4. Glenn, G.; Roberfroid, M. Dietary modulation of the human colonic microbiota: Introducing the concept of prebiotics. J. Nutr. 1995, 125, 1401-1412.

5. Gibson, G.R.; Probert, H.M.; Van Loo, J.; Rastall, R.A.; Roberfroid, M.B. Dietary modulation of the human colonic microbiota: Updating the concept of prebiotics. Nutr. Res. Rev. 2004, 17, 259-275. [CrossRef] [PubMed]

6. Bouhnik, Y.; Raskine, L.; Simoneau, G.; Vicaut, E.; Neut, C.; Flourié, B.; Brouns, F.; Bornet, F.R. The capacity of nondigestible carbohydrates to stimulate fecal bifidobacteria in healthy humans: A double-blind, randomized, placebo-controlled, parallel-group, dose-response relation study. Am. J. Clin. Nutr. 2004, 80, 1658-1664. [CrossRef] [PubMed]

7. Flint, H.J.; Scott, K.P.; Louis, P.; Duncan, S.H. The role of the gut microbiota in nutrition and health. Nat. Rev. Gastroenterol. Hepatol. 2012, 9, 577-589. [CrossRef] [PubMed]

8. Turroni, F.; Ventura, M.; Buttó, L.F.; Duranti, S.; O'Toole, P.W.; Motherway, M.O.C.; van Sinderen, D. Molecular dialogue between the human gut microbiota and the host: A lactobacillus and bifidobacterium perspective. Cell. Mol. Life Sci. 2014, 71, 183-203. [CrossRef]

9. Roberfroid, M. Health benefits of non-digestible oligosaccharides. In Dietary Fiber in Health and Disease; Springer: New York, NY, USA, 1997; pp. 211-219.

10. Morowvat, M.H.; Nezafat, N.; Ghasemi, Y.; Zare, M.H.; Mohkam, M. Probiotic potential of five lactobacillus strains isolated from traditional persian yoghurt in fars province, iran: Viewing through the window of phylogenetics. Biosci. Biotechnol. Res. Asia 2015, 12, 1265-1272.

11. Shokri, D.; Khorasgani, M.R.; Mohkam, M.; Fatemi, S.M.; Ghasemi, Y.; Taheri-Kafrani, A. The inhibition effect of lactobacilli against growth and biofilm formation of pseudomonas aeruginosa. Probiot. Antimicrob. Proteins 2018, 10, 34-42. [CrossRef]

12. Stinson, L.F.; Payne, M.S.; Keelan, J.A. Planting the seed: Origins, composition, and postnatal health significance of the fetal gastrointestinal microbiota. Crit. Rev. Microbiol. 2017, 43, 352-369. [CrossRef] 
13. Trompette, A.; Gollwitzer, E.S.; Yadava, K.; Sichelstiel, A.K.; Sprenger, N.; Ngom-Bru, C.; Blanchard, C.; Junt, T.; Nicod, L.P.; Harris, N.L.; et al. Gut microbiota metabolism of dietary fiber influences allergic airway disease and hematopoiesis. Nat. Med. 2014, 20, 159-166. [CrossRef] [PubMed]

14. Hernot, D.C.; Boileau, T.W.; Bauer, L.L.; Middelbos, I.S.; Murphy, M.R.; Swanson, K.S.; Fahey Jr, G.C. In vitro fermentation profiles, gas production rates, and microbiota modulation as affected by certain fructans, galactooligosaccharides, and polydextrose. J. Agric. Food Chem. 2009, 57, 1354-1361. [CrossRef]

15. Zhou, Z.; Zhang, Y.; Zheng, P.; Chen, X.; Yang, Y. Starch structure modulates metabolic activity and gut microbiota profile. Anaerobe 2013, 24, 71-78. [CrossRef] [PubMed]

16. Clarke, T.B.; Davis, K.M.; Lysenko, E.S.; Zhou, A.Y.; Yu, Y.; Weiser, J.N. Recognition of peptidoglycan from the microbiota by nod1 enhances systemic innate immunity. Nat. Med. 2010, 16, 228-231. [CrossRef] [PubMed]

17. Hamer, H.M.; Jonkers, D.; Venema, K.; Vanhoutvin, S.; Troost, F.; Brummer, R.J. Review article: The role of butyrate on colonic function. Aliment. Pharmacol. Ther. 2008, 27, 104-119. [CrossRef] [PubMed]

18. den Besten, G.; van Eunen, K.; Groen, A.K.; Venema, K.; Reijngoud, D.-J.; Bakker, B.M. The role of short-chain fatty acids in the interplay between diet, gut microbiota, and host energy metabolism. J. Lipid Res. 2013, 54, 2325-2340. [CrossRef] [PubMed]

19. Gibson, G.R.; Scott, K.P.; Rastall, R.A.; Tuohy, K.M.; Hotchkiss, A.; Dubert-Ferrandon, A.; Gareau, M.; Murphy, E.F.; Saulnier, D.; Loh, G.; et al. Dietary prebiotics: Current status and new definition. Food Sci. Technol. Bull. Funct. Foods 2010, 7, 1-19. [CrossRef]

20. Howlett, J.F.; Betteridge, V.A.; Champ, M.; Craig, S.A.; Meheust, A.; Jones, J.M. The definition of dietary fiber-discussions at the ninth vahouny fiber symposium: Building scientific agreement. Food Nutr. Res. 2010, 54, 5750. [CrossRef]

21. Slavin, J. Fiber and prebiotics: Mechanisms and health benefits. Nutrients 2013, 5, 1417-1435. [CrossRef]

22. Roberfroid, M.B. Prebiotics: Concept, definition, criteria, methodologies, and products. In Handbook of Prebiotics; CRC Press: Boca Raton, FL, USA, 2008; pp. 49-78.

23. Bindels, L.B.; Delzenne, N.M.; Cani, P.D.; Walter, J. Towards a more comprehensive concept for prebiotics. Nat. Rev. Gastroenterol. Hepatol. 2015, 12, 303-310. [CrossRef]

24. Scott, K.P.; Gratz, S.W.; Sheridan, P.O.; Flint, H.J.; Duncan, S.H. The influence of diet on the gut microbiota. Pharmacol. Res. 2013, 69, 52-60. [CrossRef]

25. Hutkins, R.W.; Krumbeck, J.A.; Bindels, L.B.; Cani, P.D.; Fahey, G.; Goh, Y.J.; Hamaker, B.; Martens, E.C.; Mills, D.A.; Rastal, R.A.; et al. Prebiotics: Why definitions matter. Curr. Opin. Biotechnol. 2016, 37, 1-7. [CrossRef] [PubMed]

26. Scott, K.P.; Martin, J.C.; Duncan, S.H.; Flint, H.J. Prebiotic stimulation of human colonic butyrate-producing bacteria and bifidobacteria, in vitro. FEMS Microbiol. Ecol. 2014, 87, 30-40. [CrossRef] [PubMed]

27. Macfarlane, G.; Steed, H.; Macfarlane, S. Bacterial metabolism and health-related effects of galacto-oligosaccharides and other prebiotics. J. Appl. Microbiol. 2008, 104, 305-344. [CrossRef] [PubMed]

28. Johnson, C.R.; Combs, G.F.; Thavarajah, P. Lentil (lens culinaris 1.): A prebiotic-rich whole food legume. Food Res. Int. 2013, 51, 107-113. [CrossRef]

29. Whelan, K. Mechanisms and effectiveness of prebiotics in modifying the gastrointestinal microbiota for the management of digestive disorders. Proc. Nutr. Soc. 2013, 72, 288-298. [CrossRef] [PubMed]

30. Fuentes-Zaragoza, E.; Sánchez-Zapata, E.; Sendra, E.; Sayas, E.; Navarro, C.; Fernández-López, J.; Pérez-Alvarez, J.A. Resistant starch as prebiotic: A review. Starch-Stärke 2011, 63, 406-415. [CrossRef]

31. Ze, X.; Duncan, S.H.; Louis, P.; Flint, H.J. Ruminococcus bromii is a keystone species for the degradation of resistant starch in the human colon. ISME J. 2012, 6, 1535-1543. [CrossRef]

32. Costabile, A.; Fava, F.; Röytiö, H.; Forssten, S.D.; Olli, K.; Klievink, J.; Rowland, I.R.; Ouwehand, A.C.; Rastall, R.A.; Gibson, G.R.; et al. Impact of polydextrose on the faecal microbiota: A double-blind, crossover, placebo-controlled feeding study in healthy human subjects. Br. J. Nutr. 2012, 108, 471-481. [CrossRef]

33. Yoo, H.-D.; Kim, D.-J.; Paek, S.-H.; Oh, S.-E. Plant cell wall polysaccharides as potential resources for the development of novel prebiotics. Biomol. Ther. 2012, 20, 371-379. [CrossRef]

34. Gullón, B.; Gómez, B.; Martínez-Sabajanes, M.; Yáñez, R.; Parajó, J.; Alonso, J. Pectic oligosaccharides: Manufacture and functional properties. Trends Food Sci. Technol. 2013, 30, 153-161. [CrossRef]

35. Tzounis, X.; Rodriguez-Mateos, A.; Vulevic, J.; Gibson, G.R.; Kwik-Uribe, C.; Spencer, J.P. Prebiotic evaluation of cocoa-derived flavanols in healthy humans by using a randomized, controlled, double-blind, crossover intervention study. Am. J. Clin. Nutr. 2011, 93, 62-72. [CrossRef] [PubMed] 
36. Varzakas, T.; Kandylis, P.; Dimitrellou, D.; Salamoura, C.; Zakynthinos, G.; Proestos, C. Innovative and fortified food: Probiotics, prebiotics, gmos, and superfood. In Preparation and Processing of Religious and Cultural Foods; Elsevier: London, UK, 2018; pp. 67-129.

37. Al-Sheraji, S.; Ismail, A.; Manap, M.; Mustafa, S.; Yusof, R.; Hassan, F. Prebiotics as functional foods: A review. J. Funct Foods 2013, 5, 1542-1553. [CrossRef]

38. Panesar, P.S.; Kumari, S.; Panesar, R. Biotechnological approaches for the production of prebiotics and their potential applications. Crit. Rev. Biotechnol. 2013, 33, 345-364. [CrossRef] [PubMed]

39. Havenaar, R.; Bonnin-Marol, S.; Van Dokkum, W.; Petitet, S.; Schaafsma, G. Inulin: Fermentation and microbial ecology in the intestinal tract. Food Rev. Int. 1999, 15, 109-120. [CrossRef]

40. Sangeetha, P.; Ramesh, M.; Prapulla, S. Recent trends in the microbial production, analysis and application of fructooligosaccharides. Trends Food Sci. Technol. 2005, 16, 442-457. [CrossRef]

41. Yun, J.W. Fructooligosaccharides-Occurrence, preparation, and application. Enzym. Microb. Technol. 1996, 19, 107-117. [CrossRef]

42. Prapulla, S.; Subhaprada, V.; Karanth, N. Microbial production of oligosaccharides: A review. Adv. Appl. Microbiol. 2000, 47, 299-343.

43. Barreteau, H.; Delattre, C.; Michaud, P. Production of oligosaccharides as promising new food additive generation. Food Technol. Biotechnol. 2006, 44, 323-333.

44. Caicedo, L.; Silva, E.; Sánchez, O. Semibatch and continuous fructooligosaccharides production by aspergillus sp. N74 in a mechanically agitated airlift reactor. J. Chem. Technol. Biotechnol. 2009, 84, 650-656. [CrossRef]

45. Sangeetha, P.; Ramesh, M.; Prapulla, S. Production of fructo-oligosaccharides by fructosyl transferase from aspergillus oryzae cfr 202 and aureobasidium pullulans cfr 77. Process Biochem. 2004, 39, 755-760. [CrossRef]

46. Mohkam, M.; Nezafat, N.; Berenjian, A.; Negahdaripour, M.; Behfar, A.; Ghasemi, Y. Role of bacillus genus in the production of value-added compounds. In Bacilli and Agrobiotechnology; Springer: Basel, Switzerland, 2016; pp. 1-33.

47. Chen, W.-C.; Liu, C.-H. Production of $\beta$-fructofuranosidase by aspergillus japonicus. Enzym. Microb. Technol. 1996, 18, 153-160. [CrossRef]

48. Prata, M.B.; Mussatto, S.I.; Rodrigues, L.R.; Teixeira, J.A. Fructooligosaccharide production by penicillium expansum. Biotechnol. Lett. 2010, 32, 837-840. [CrossRef]

49. Maiorano, A.E.; Piccoli, R.M.; Da Silva, E.S.; de Andrade Rodrigues, M.F. Microbial production of fructosyltransferases for synthesis of pre-biotics. Biotechnol. Lett. 2008, 30, 1867-1877. [CrossRef]

50. Mussatto, S.I.; Aguilar, C.N.; Rodrigues, L.R.; Teixeira, J.A. Fructooligosaccharides and $\beta$-fructofuranosidase production by aspergillus japonicus immobilized on lignocellulosic materials. J. Mol. Catal. B Enzym. 2009, 59, 76-81. [CrossRef]

51. Jong, W.Y.; Seung, K.S. The production of high-content fructo-oligosaccharides from sucrose by the mixed-enzyme system of fructosyltransferase and glucose oxidase. Biotechnol. Lett. 1993, 15, 573-576. [CrossRef]

52. Sheu, D.C.; Duan, K.J.; Cheng, C.Y.; Bi, J.L.; Chen, J.Y. Continuous production of high-content fructooligosaccharides by a complex cell system. Biotechnol. Prog. 2002, 18, 1282-1286. [CrossRef]

53. Yun, J.W.; Lee, M.G.; Song, S.K. Batch production of high-content fructo-oligosaccharides from sucrose by the mixed-enzyme system of $\beta$-fructofuranosidase and glucose oxidase. J. Ferment. Bioeng. 1994, 77, 159-163. [CrossRef]

54. Lin, T.-J.; Lee, Y.-C. High-content fructooligosaccharides production using two immobilized microorganisms in an internal-loop airlift bioreactor. J. Chin. Inst. Chem. Eng. 2008, 39, 211-217. [CrossRef]

55. Nishizawa, K.; Nakajima, M.; Nabetani, H. Kinetic study on transfructosylation by. Beta.-fructofuranosidase from aspergillus niger atcc 20611 and availability of a membrane reactor for fructooligosaccharide production. Food Sci. Technol. Res. 2001, 7, 39-44. [CrossRef]

56. Crittenden, R.; Playne, M. Purification of food-grade oligosaccharides using immobilised cells of zymomonas mobilis. Appl. Microbiol. Biotechnol. 2002, 58, 297-302.

57. Goulas, A.; Tzortzis, G.; Gibson, G.R. Development of a process for the production and purification of $\alpha$-and $\beta$-galactooligosaccharides from bifidobacterium bifidum ncimb 41171. Int. Dairy J. 2007, 17, 648-656. [CrossRef]

58. Hernández, O.; Ruiz-Matute, A.I.; Olano, A.; Moreno, F.J.; Sanz, M.L. Comparison of fractionation techniques to obtain prebiotic galactooligosaccharides. Int. Dairy J. 2009, 19, 531-536. [CrossRef] 
59. Yoon, S.-H.; Mukerjea, R.; Robyt, J.F. Specificity of yeast (saccharomyces cerevisiae) in removing carbohydrates by fermentation. Carbohydr. Res. 2003, 338, 1127-1132. [CrossRef]

60. Palcic, M.M. Biocatalytic synthesis of oligosaccharides. Curr. Opin. Biotechnol. 1999, 10, 616-624. [CrossRef]

61. Weijers, C.A.; Franssen, M.C.; Visser, G.M. Glycosyltransferase-catalyzed synthesis of bioactive oligosaccharides. Biotechnol. Adv. 2008, 26, 436-456. [CrossRef]

62. Koizumi, S.; Endo, T.; Tabata, K.; Ozaki, A. Large-scale production of udp-galactose and globotriose by coupling metabolically engineered bacteria. Nat. Biotechnol. 1998, 16, 847-850. [CrossRef]

63. Albermann, C.; Piepersberg, W.; Wehmeier, U.F. Synthesis of the milk oligosaccharide 2 '-fucosyllactose using recombinant bacterial enzymes. Carbohydr. Res. 2001, 334, 97-103. [CrossRef]

64. Priem, B.; Gilbert, M.; Wakarchuk, W.W.; Heyraud, A.; Samain, E. A new fermentation process allows large-scale production of human milk oligosaccharides by metabolically engineered bacteria. Glycobiology 2002, 12, 235-240. [CrossRef]

65. Monsan, P.; Paul, F. Enzymatic synthesis of oligosaccharides. FEMS Microbiol. Rev. 1995, 16, 187-192. [CrossRef]

66. Osman, A.; Tzortzis, G.; Rastall, R.A.; Charalampopoulos, D. Bbgiv is an important bifidobacterium $\beta$-galactosidase for the synthesis of prebiotic galactooligosaccharides at high temperatures. J. Agric. Food Chem. 2012, 60, 740-748. [CrossRef]

67. Prenosil, J.; Stuker, E.; Bourne, J. Formation of oligosaccharides during enzymatic lactose: Part i: State of art. Biotechnol. Bioeng. 1987, 30, 1019-1025. [CrossRef]

68. Rabiu, B.A.; Jay, A.J.; Gibson, G.R.; Rastall, R.A. Synthesis and fermentation properties of novel galacto-oligosaccharides by $\beta$-galactosidases frombifidobacterium species. Appl. Environ. Microbiol. 2001, 67, 2526-2530. [CrossRef]

69. Zarate, S.; Lopez-Leiva, M. Oligosaccharide formation during enzymatic lactose hydrolysis: A literature review. J. Food Prot. 1990, 53, 262-274. [CrossRef]

70. Neri, D.F.; Balcão, V.M.; Costa, R.S.; Rocha, I.C.; Ferreira, E.M.; Torres, D.P.; Rodrigues, L.R.; Carvalho, L.B.; Teixeira, J.A. Galacto-oligosaccharides production during lactose hydrolysis by free aspergillus oryzae $\beta$-galactosidase and immobilized on magnetic polysiloxane-polyvinyl alcohol. Food Chem. 2009, 115, 92-99. [CrossRef]

71. Iqbal, S.; Nguyen, T.-H.; Nguyen, T.T.; Maischberger, T.; Haltrich, D. B-galactosidase from lactobacillus plantarum wcfs1: Biochemical characterization and formation of prebiotic galacto-oligosaccharides. Carbohydr. Res. 2010, 345, 1408-1416. [CrossRef]

72. Iqbal, S.; Nguyen, T.-H.; Nguyen, H.A.; Nguyen, T.T.; Maischberger, T.; Kittl, R.; Haltrich, D. Characterization of a heterodimeric gh2 $\beta$-galactosidase from lactobacillus sakei $1 \mathrm{~b} 790$ and formation of prebiotic galacto-oligosaccharides. J. Agric. Food Chem. 2011, 59, 3803-3811. [CrossRef]

73. Yi, S.H.; Alli, I.; Park, K.H.; Lee, B. Overexpression and characterization of a novel transgalactosylic and hydrolytic $\beta$-galactosidase from a human isolate bifidobacterium breve b24. New Biotechnol. 2011, 28, 806-813. [CrossRef]

74. Fukuda, H.; Hama, S.; Tamalampudi, S.; Noda, H. Whole-cell biocatalysts for biodiesel fuel production. Trends Biotechnol. 2008, 26, 668-673. [CrossRef]

75. Burton, S.G.; Cowan, D.A.; Woodley, J.M. The search for the ideal biocatalyst. Nat. Biotechnol. 2002, $20,37-45$. [CrossRef]

76. Schmid, A.; Dordick, J.; Hauer, B.; Kiener, A.; Wubbolts, M.; Witholt, B. Industrial biocatalysis today and tomorrow. Nature 2001, 409, 258-268. [CrossRef] [PubMed]

77. Onishi, N.; Yokozeki, K. Gluco-oligosaccharide and galacto-oligosaccharide production by rhodotorula minuta ifo879. J. Ferment. Bioeng. 1996, 82, 124-127. [CrossRef]

78. Onishi, N.; Yamashiro, A.; Yokozeki, K. Production of galacto-oligosaccharide from lactose by sterigmatomyces elviae cbs8119. Appl. Environ. Microbiol. 1995, 61, 4022-4025. [PubMed]

79. Onishi, N.; Kira, I.; Yokozeki, K. Galacto-oligosaccharide production from lactose by sirobasidium magnum cbs6803. Lett. Appl. Microbiol. 1996, 23, 253-256. [CrossRef] [PubMed]

80. Onishi, N.; Tanaka, T. Purification and properties of a galacto-and gluco-oligosaccharide-producing $\beta$-glycosidase from rhodotorula minuta ifo879. J. Ferment. Bioeng. 1996, 82, 439-443. [CrossRef]

81. Onishi, N.; Tanaka, T. Purification and characterization of galacto-oligosaccharide-producing $\beta$-galactosidase from sirobasidium magnum. Lett. Appl. Microbiol. 1997, 24, 82-86. [CrossRef] 
82. Li, Y.; Lu, L.; Wang, H.; Xu, X.; Xiao, M. Cell surface engineering of a $\beta$-galactosidase for galactooligosaccharide synthesis. Appl. Environ. Microbiol. 2009, 75, 5938-5942. [CrossRef] [PubMed]

83. Osman, A.; Tzortzis, G.; Rastall, R.A.; Charalampopoulos, D. A comprehensive investigation of the synthesis of prebiotic galactooligosaccharides by whole cells of bifidobacterium bifidum ncimb 41171. J. Biotechnol. 2010, 150, 140-148. [CrossRef] [PubMed]

84. Ji, E.-S.; Park, N.-H.; Oh, D.-K. Galacto-oligosaccharide production by a thermostable recombinant $\beta$-galactosidase from thermotoga maritima. World J. Microbiol. Biotechnol. 2005, 21, 759-764. [CrossRef]

85. Terpe, K. Overview of bacterial expression systems for heterologous protein production: From molecular and biochemical fundamentals to commercial systems. Appl. Microbiol. Biotechnol. 2006, 72, 211-222. [CrossRef]

86. Demain, A.L.; Vaishnav, P. Production of recombinant proteins by microbes and higher organisms. Biotechnol. Adv. 2009, 27, 297-306. [CrossRef] [PubMed]

87. Yin, J.; Li, G.; Ren, X.; Herrler, G. Select what you need: A comparative evaluation of the advantages and limitations of frequently used expression systems for foreign genes. J. Biotechnol. 2007, 127, 335-347. [CrossRef]

88. Porro, D.; Sauer, M.; Branduardi, P.; Mattanovich, D. Recombinant protein production in yeasts. Mol. Biotechnol. 2005, 31, 245-259. [CrossRef]

89. Buckholz, R.G.; Gleeson, M.A. Yeast systems for the commercial production of heterologous proteins. Nat. Biotechnol. 1991, 9, 1067-1072. [CrossRef]

90. Flint, H.J.; Duncan, S.H.; Scott, K.P.; Louis, P. Interactions and competition within the microbial community of the human colon: Links between diet and health. Environ. Microbiol. 2007, 9, 1101-1111. [CrossRef] [PubMed]

91. Cecchini, D.A.; Laville, E.; Laguerre, S.; Robe, P.; Leclerc, M.; Doré, J.; Henrissat, B.; Remaud-Siméon, M.; Monsan, P.; Potocki-Véronèse, G. Functional metagenomics reveals novel pathways of prebiotic breakdown by human gut bacteria. PLoS ONE 2013, 8, e72766. [CrossRef] [PubMed]

92. Belenguer, A.; Duncan, S.H.; Calder, A.G.; Holtrop, G.; Louis, P.; Lobley, G.E.; Flint, H.J. Two routes of metabolic cross-feeding between bifidobacterium adolescentis and butyrate-producing anaerobes from the human gut. Appl. Environ. Microbiol. 2006, 72, 3593-3599. [CrossRef]

93. Ryan, S.M.; Fitzgerald, G.F.; van Sinderen, D. Screening for and identification of starch-, amylopectin-, and pullulan-degrading activities in bifidobacterial strains. Appl. Environ. Microbiol. 2006, 72, 5289-5296. [CrossRef]

94. Rossi, M.; Corradini, C.; Amaretti, A.; Nicolini, M.; Pompei, A.; Zanoni, S.; Matteuzzi, D. Fermentation of fructooligosaccharides and inulin by bifidobacteria: A comparative study of pure and fecal cultures. Appl. Environ. Microbiol. 2005, 71, 6150-6158. [CrossRef]

95. Falony, G.; Vlachou, A.; Verbrugghe, K.; De Vuyst, L. Cross-feeding between bifidobacterium longum bb536 and acetate-converting, butyrate-producing colon bacteria during growth on oligofructose. Appl. Environ. Microbiol. 2006, 72, 7835-7841. [CrossRef]

96. Walker, A.W.; Duncan, S.H.; Leitch, E.C.M.; Child, M.W.; Flint, H.J. Ph and peptide supply can radically alter bacterial populations and short-chain fatty acid ratios within microbial communities from the human colon. Appl. Environ. Microbiol. 2005, 71, 3692-3700. [CrossRef]

97. Duncan, S.H.; Louis, P.; Thomson, J.M.; Flint, H.J. The role of ph in determining the species composition of the human colonic microbiota. Environ. Microbiol. 2009, 11, 2112-2122. [CrossRef] [PubMed]

98. Wilson, B.; Whelan, K. Prebiotic inulin-type fructans and galacto-oligosaccharides: Definition, specificity, function, and application in gastrointestinal disorders. J. Gastroenterol. Hepatol. 2017, 32, 64-68. [CrossRef] [PubMed]

99. Hunter, J.; Tuffnell, Q.; Lee, A. Controlled trial of oligofructose in the management of irritable bowel syndrome. J. Nutr. 1999, 129, 1451S-1453S. [CrossRef] [PubMed]

100. Olesen, M.; Gudmand-Høyer, E. Efficacy, safety, and tolerability of fructooligosaccharides in the treatment of irritable bowel syndrome. Am. J. Clin. Nutr. 2000, 72, 1570-1575. [CrossRef] [PubMed]

101. Paineau, D.; Payen, F.; Panserieu, S.; Coulombier, G.; Sobaszek, A.; Lartigau, I.; Brabet, M.; Galmiche, J.-P.; Tripodi, D.; Sacher-Huvelin, S.; et al. The effects of regular consumption of short-chain fructo-oligosaccharides on digestive comfort of subjects with minor functional bowel disorders. Br. J. Nutr. 2008, 99, 311-318. [CrossRef] [PubMed] 
102. Silk, D.; Davis, A.; Vulevic, J.; Tzortzis, G.; Gibson, G. Clinical trial: The effects of a trans-galactooligosaccharide prebiotic on faecal microbiota and symptoms in irritable bowel syndrome. Aliment. Pharmacol. Ther. 2009, 29, 508-518. [CrossRef] [PubMed]

103. Lindsay, J.O.; Whelan, K.; Stagg, A.J.; Gobin, P.; Al-Hassi, H.O.; Rayment, N.; Kamm, M.; Knight, S.C.; Forbes, A. Clinical, microbiological, and immunological effects of fructo-oligosaccharide in patients with crohn's disease. Gut 2006, 55, 348-355. [CrossRef]

104. Benjamin, J.L.; Hedin, C.R.; Koutsoumpas, A.; Ng, S.C.; McCarthy, N.E.; Hart, A.L.; Kamm, M.A.; Sanderson, J.D.; Knight, S.C.; Forbes, A.; et al. Randomised, double-blind, placebo-controlled trial of fructo-oligosaccharides in active crohn's disease. Gut 2011, 60, 923-929. [CrossRef]

105. Joossens, M.; De Preter, V.; Ballet, V.; Verbeke, K.; Rutgeerts, P.; Vermeire, S. Effect of oligofructose-enriched inulin (of-in) on bacterial composition and disease activity of patients with crohn's disease: Results from a double-blinded randomised controlled trial. Gut 2011, 61, 958. [CrossRef]

106. Candela, M.; Guidotti, M.; Fabbri, A.; Brigidi, P.; Franceschi, C.; Fiorentini, C. Human intestinal microbiota: Cross-talk with the host and its potential role in colorectal cancer. Crit. Rev. Microbiol. 2011, 37, 1-14. [CrossRef] [PubMed]

107. Louis, P.; Flint, H.J. Diversity, metabolism and microbial ecology of butyrate-producing bacteria from the human large intestine. FEMS Microbiol. Lett. 2009, 294, 1-8. [CrossRef] [PubMed]

108. Davis, C.D.; Milner, J.A. Gastrointestinal microflora, food components and colon cancer prevention. J. Nutr. Biochem. 2009, 20, 743-752. [CrossRef] [PubMed]

109. Pool-Zobel, B.L. Inulin-type fructans and reduction in colon cancer risk: Review of experimental and human data. Br. J. Nutr. 2005, 93, S73-S90. [CrossRef]

110. Rafter, J.; Bennett, M.; Caderni, G.; Clune, Y.; Hughes, R.; Karlsson, P.C.; Klinder, A.; O’Riordan, M.; O'Sullivan, G.C.; Pool-Zobel, B.; et al. Dietary synbiotics reduce cancer risk factors in polypectomized and colon cancer patients. Am. J. Clin. Nutr. 2007, 85, 488-496. [CrossRef] [PubMed]

111. Patel, R.M.; Denning, P.W. Therapeutic use of prebiotics, probiotics, and postbiotics to prevent necrotizing enterocolitis: What is the current evidence? Clin. Perinatol. 2013, 40, 11-25. [CrossRef] [PubMed]

112. Knol, J.; Boehm, G.; Lidestri, M.; Negretti, F.; Jelinek, J.; Agosti, M.; Stahl, B.; Marini, A.; Mosca, F. Increase of faecal bifidobacteria due to dietary oligosaccharides induces a reduction of clinically relevant pathogen germs in the faeces of formula-fed preterm infants. Acta Paediatr. 2005, 94, 31-33. [CrossRef]

113. Boehm, G.; Lidestri, M.; Casetta, P.; Jelinek, J.; Negretti, F.; Stahl, B.; Marini, A. Supplementation of a bovine milk formula with an oligosaccharide mixture increases counts of faecal bifidobacteria in preterm infants. Arch. Dis. Childhood-Fetal Neonatal Ed. 2002, 86, F178-F181. [CrossRef]

114. Kapiki, A.; Costalos, C.; Oikonomidou, C.; Triantafyllidou, A.; Loukatou, E.; Pertrohilou, V. The effect of a fructo-oligosaccharide supplemented formula on gut flora of preterm infants. Early Hum. Dev. 2007, 83, 335-339. [CrossRef]

115. Indrio, F.; Riezzo, G.; Raimondi, F.; Bisceglia, M.; Cavallo, L.; Francavilla, R. Effects of probiotic and prebiotic on gastrointestinal motility in newborns. J. Physiol. Pharmacol. 2009, 60, $27-31$.

116. Indrio, F.; Riezzo, G.; Raimondi, F.; Francavilla, R.; Montagna, O.; Valenzano, M.L.; Cavallo, L.; Boehm, G. Prebiotics improve gastric motility and gastric electrical activity in preterm newborns. J. Pediatr. Gastroenterol. Nutr. 2009, 49, 258-261. [CrossRef] [PubMed]

117. Labayen, I.; Forga, L.; Gonzalez, A.; Lenoir-Wijnkoop, I.; Martinez, J.A. Relationship between lactose digestion, gastrointestinal transit time and symptoms in lactose malabsorbers after dairy consumption. Aliment. Pharmacol. Ther. 2001, 15, 543-549. [CrossRef] [PubMed]

118. Srinivasjois, R.; Rao, S.; Patole, S. Prebiotic supplementation of formula in preterm neonates: A systematic review and meta-analysis of randomised controlled trials. Clin. Nutr. 2009, 28, 237-242. [CrossRef] [PubMed]

119. Klinder, A.; Gietl, E.; Hughes, R.; Jonkers, N.; Karlsson, P.; McGlyn, H.; Pistoli, S.; Tuohy, K.; Rafter, J.; Rowland, I.; et al. Gut fermentation products of insulin-derived prebiotics beneficially modulate markers of tumour progression in human colon tumour cells. Int. J. Cancer Prev. 2004, 1, 19-32.

120. Verghese, M.; Rao, D.; Chawan, C.; Shackelford, L. Dietary inulin suppresses azoxymethane-induced preneoplastic aberrant crypt foci in mature fisher 344 rats. J. Nutr. 2002, 132, 2804-2808. [CrossRef] [PubMed] 
121. Denji, K.A.; Mansour, M.R.; Akrami, R.; Ghobadi, S.; Jafarpour, S.; Mirbeygi, S. Effect of dietary prebiotic mannan oligosaccharide (mos) on growth performance, intestinal microflora, body composition, haematological and blood serum biochemical parameters of rainbow trout (oncorhynchus mykiss) juveniles. J. Fish. Aquat. Sci. 2015, 10, 255.

122. Klatt, N.R.; Canary, L.A.; Sun, X.; Vinton, C.L.; Funderburg, N.T.; Morcock, D.R.; Quiñones, M.; Deming, C.B.; Perkins, M.; Hazuda, D.J.; et al. Probiotic/prebiotic supplementation of antiretrovirals improves gastrointestinal immunity in siv-infected macaques. J. Clin. Investig. 2013, 123, 903-907. [CrossRef]

123. Langen, L.V.; Mirjam, A.; Dieleman, L.A. Prebiotics in chronic intestinal inflammation. Inflamm. Bowel Dis. 2009, 15, 454-462. [CrossRef]

124. Steed, H.; Macfarlane, S. Mechanisms of prebiotic impact on health. In Prebiotics and Probiotics Science and Technology; Springer: New York, NY, USA, 2009; pp. 135-161.

125. Oyofo, B.; DeLoach, J.; Corrier, D.; Norman, J.; Ziprin, R.; Mollenhauer, H. Prevention of salmonella typhimurium colonization of broilers with d-mannose. Poult. Sci. 1989, 68, 1357-1360. [CrossRef]

126. Thorburn, A.N.; Macia, L.; Mackay, C.R. Diet, metabolites, and "western-lifestyle" inflammatory diseases. Immunity 2014, 40, 833-842. [CrossRef]

127. Fujiwara, R.; Takemura, N.; Watanabe, J.; Sonoyama, K. Maternal consumption of fructo-oligosaccharide diminishes the severity of skin inflammation in offspring of nc/nga mice. Br. J. Nutr. 2010, 103, 530-538. [CrossRef]

128. Shadid, R.; Haarman, M.; Knol, J.; Theis, W.; Beermann, C.; Rjosk-Dendorfer, D.; Schendel, D.J.; Koletzko, B.V.; Krauss-Etschmann, S. Effects of galactooligosaccharide and long-chain fructooligosaccharide supplementation during pregnancy on maternal and neonatal microbiota and immunity-A randomized, double-blind, placebo-controlled study. Am. J. Clin. Nutr. 2007, 86, 1426-1437. [CrossRef] [PubMed]

129. Firmansyah, A.; Pramita, G.; Carrie Fassler, A.; Haschke, F.; Link-Amster, H. Improved humoral immune response to measles vaccine in infants receiving infant cereal with fructooligosaccharides. J. Pediatr. Gastroenterol. Nutr. 2001, 31, A521.

130. Langkamp-Henken, B.; Bender, B.S.; Gardner, E.M.; Herrlinger-Garcia, K.A.; Kelley, M.J.; Murasko, D.M.; Schaller, J.P.; Stechmiller, J.K.; Thomas, D.J.; Wood, S.M. Nutritional formula enhanced immune function and reduced days of symptoms of upper respiratory tract infection in seniors. J. Am. Geriatr. Soc. 2004, 52, 3-12. [CrossRef] [PubMed]

131. Lomax, A.R.; Cheung, L.V.; Tuohy, K.M.; Noakes, P.S.; Miles, E.A.; Calder, P.C. B2-1 fructans have a bifidogenic effect in healthy middle-aged human subjects but do not alter immune responses examined in the absence of an in vivo immune challenge: Results from a randomised controlled trial. Br. J. Nutr. 2012, 108, 1818-1828. [CrossRef] [PubMed]

132. Saavedra, J.; Tschernia, A.; Moore, N.; Abi-Hanna, A.; Coletta, F.; Emenhiser, C.; Yolken, R. Gastro-intestinal function in infants consuming a weaning food supplemented with oligofructose, a prebiotic. J. Pediatr. Gastroenterol. Nutr. 1999, 29, 513. [CrossRef]

133. Tschernia, A.; Moore, N.; Abi-Hanna, A.; Yolken, R.; Coletta, F.; Emenhiser, C.; Saavedra, J. Effects of long-term consumption of a weaning food supplemented with oligofructose, a prebiotic, on general infant health status. J. Pediatr. Gastroenterol. Nutr. 1999, 29, 503. [CrossRef]

134. Clarke, S.; Green-Johnson, J.; Brooks, S.; Ramdath, D.; Bercik, P.; Avila, C.; Inglis, G.; Green, J.; Yanke, L.; Selinger, L. B2-1 fructan supplementation alters host immune responses in a manner consistent with increased exposure to microbial components: Results from a double-blinded, randomised, cross-over study in healthy adults. Br. J. Nutr. 2016, 115, 1748-1759. [CrossRef]

135. Lomax, A.R.; Cheung, L.V.; Noakes, P.S.; Miles, E.A.; Calder, P.C. Inulin-type $\beta 2-1$ fructans have some effect on the antibody response to seasonal influenza vaccination in healthy middle-aged humans. Front. Immunol. 2015, 6, 490. [CrossRef]

136. Grüber, C.; van Stuijvenberg, M.; Mosca, F.; Moro, G.; Chirico, G.; Braegger, C.P.; Riedler, J.; Boehm, G.; Wahn, U.; MIPS 1 Working Group. Reduced occurrence of early atopic dermatitis because of immunoactive prebiotics among low-atopy-risk infants. J. Allergy Clin. Immunol. 2010, 126, 791-797.

137. Moro, G.; Arslanoglu, S.; Stahl, B.; Jelinek, J.; Wahn, U.; Boehm, G. A mixture of prebiotic oligosaccharides reduces the incidence of atopic dermatitis during the first six months of age. Arch. Dis. Childhood 2006, 91, 814-819. [CrossRef] [PubMed] 
138. Guigoz, Y.; Rochat, F.; Perruisseau-Carrier, G.; Rochat, I.; Schiffrin, E. Effects of oligosaccharide on the faecal flora and non-specific immune system in elderly people. Nutr. Res. 2002, 22, 13-25. [CrossRef]

139. Vulevic, J.; Drakoularakou, A.; Yaqoob, P.; Tzortzis, G.; Gibson, G.R. Modulation of the fecal microflora profile and immune function by a novel trans-galactooligosaccharide mixture (b-gos) in healthy elderly volunteers. Am. J. Clin. Nutr. 2008, 88, 1438-1446. [PubMed]

140. Vulevic, J.; Juric, A.; Walton, G.E.; Claus, S.P.; Tzortzis, G.; Toward, R.E.; Gibson, G.R. Influence of galacto-oligosaccharide mixture (b-gos) on gut microbiota, immune parameters and metabonomics in elderly persons. Br. J. Nutr. 2015, 114, 586-595. [CrossRef] [PubMed]

141. Kukkonen, K.; Savilahti, E.; Haahtela, T.; Juntunen-Backman, K.; Korpela, R.; Poussa, T.; Tuure, T.; Kuitunen, M. Probiotics and prebiotic galacto-oligosaccharides in the prevention of allergic diseases: A randomized, double-blind, placebo-controlled trial. J. Allergy Clin. Immunol. 2007, 119, 192-198. [CrossRef] [PubMed]

142. Gaman, A.; Kuo, B. Neuromodulatory processes of the brain-gut axis. Neuromodulation 2008, 11, $249-259$. [CrossRef] [PubMed]

143. Mudd, A.T.; Alexander, L.S.; Berding, K.; Waworuntu, R.V.; Berg, B.M.; Donovan, S.M.; Dilger, R.N. Dietary prebiotics, milk fat globule membrane, and lactoferrin affects structural neurodevelopment in the young piglet. Front. Pediatr. 2016, 4, 4. [CrossRef]

144. Grenham, S.; Clarke, G.; Cryan, J.F.; Dinan, T.G. Brain-gut-microbe communication in health and disease. Front. Physiol. 2011, 2, 94. [CrossRef]

145. Liu, X.; Cao, S.; Zhang, X. Modulation of gut microbiota-brain axis by probiotics, prebiotics, and diet. J. Agric. Food Chem. 2015, 63, 7885-7895. [CrossRef]

146. Forsythe, P.; Bienenstock, J.; Kunze, W.A. Vagal pathways for microbiome-brain-gut axis communication. In Microbial Endocrinology: The Microbiota-Gut-Brain Axis in Health and Disease; Springer: New York, NY, USA, 2014; pp. 115-133.

147. Savignac, H.M.; Corona, G.; Mills, H.; Chen, L.; Spencer, J.P.; Tzortzis, G.; Burnet, P.W. Prebiotic feeding elevates central brain derived neurotrophic factor, n-methyl-d-aspartate receptor subunits and d-serine. Neurochem. Int. 2013, 63, 756-764. [CrossRef]

148. Williams, S.; Chen, L.; Savignac, H.M.; Tzortzis, G.; Anthony, D.C.; Burnet, P.W. Neonatal prebiotic (bgos) supplementation increases the levels of synaptophysin, glun2a-subunits and bdnf proteins in the adult rat hippocampus. Synapse 2016, 70, 121-124. [CrossRef] [PubMed]

149. Sudo, N.; Chida, Y.; Aiba, Y.; Sonoda, J.; Oyama, N.; Yu, X.N.; Kubo, C.; Koga, Y. Postnatal microbial colonization programs the hypothalamic-pituitary-adrenal system for stress response in mice. J. Physiol. 2004, 558, 263-275. [CrossRef] [PubMed]

150. Heijtz, R.D.; Wang, S.; Anuar, F.; Qian, Y.; Björkholm, B.; Samuelsson, A.; Hibberd, M.L.; Forssberg, H.; Pettersson, S. Normal gut microbiota modulates brain development and behavior. Proc. Natl. Acad. Sci. USA 2011, 108, 3047-3052. [CrossRef] [PubMed]

151. Neufeld, K.; Kang, N.; Bienenstock, J.; Foster, J. Reduced anxiety-like behavior and central neurochemical change in germ-free mice. Neurogastroenterol. Motil. 2011, 23, 255-e119. [CrossRef] [PubMed]

152. Nelson, E.D.; Ramberg, J.E.; Best, T.; Sinnott, R.A. Neurologic effects of exogenous saccharides: A review of controlled human, animal, and in vitro studies. Nutr. Neurosci. 2012, 15, 149-162. [CrossRef] [PubMed]

153. Best, T.; Howe, P.; Bryan, J.; Buckley, J.; Scholey, A. Acute effects of a dietary non-starch polysaccharide supplement on cognitive performance in healthy middle-aged adults. Nutr. Neurosci. 2015, 18, 76-86. [CrossRef] [PubMed]

154. Best, T.; Kemps, E.; Bryan, J. Saccharide effects on cognition and well-being in middle-aged adults: A randomized controlled trial. Dev. Neuropsychol. 2009, 35, 66-80. [CrossRef]

155. Han, H.S.; Jang, J.-H.; Jang, J.H.; Choi, J.S.; Kim, Y.J.; Lee, C.; Lim, S.H.; Lee, H.-K.; Lee, J. Water extract of triticum aestivum 1 . And its components demonstrate protective effect in a model of vascular dementia. J. Med. Food 2010, 13, 572-578. [CrossRef]

156. Schmidt, K.; Cowen, P.J.; Harmer, C.J.; Tzortzis, G.; Errington, S.; Burnet, P.W. Prebiotic intake reduces the waking cortisol response and alters emotional bias in healthy volunteers. Psychopharmacology 2015, 232, 1793-1801. [CrossRef] 
157. van den Berg, J.P.; Westerbeek, E.; Bröring-Starre, T.; Garssen, J.; van Elburg, R.M. Neurodevelopment of preterm infants at 24 month after neonatal supplementation of a prebiotic mix: A randomized trial. J. Pediatr. Gastroenterol. Nutr. 2016, 63, 270-276. [CrossRef]

158. Smith, A.P.; Sutherland, D.; Hewlett, P. An investigation of the acute effects of oligofructose-enriched inulin on subjective wellbeing, mood and cognitive performance. Nutrients 2015, 7, 8887-8896. [CrossRef] [PubMed]

159. Smith, A.P. The concept of well-being: Relevance to nutrition research. Br. J. Nutr. 2005, 93, S1-S5. [CrossRef] [PubMed]

160. Waworuntu, R.; Hain, H.; Chang, Q.; Thiede, L.; Hanania, T.; Berg, B. Dietary prebiotics improve memory and social interactions while reducing anxiety when provided early in life to normally developing rodents (637.5). FASEB J. 2014, 28, 637.5.

161. Messaoudi, M.; Rozan, P.; Nejdi, A.; Hidalgo, S.; Desor, D. Behavioural and cognitive effects of oligofructose-enriched inulin in rats. Br. J. Nutr. 2005, 93, S27-S30. [CrossRef] [PubMed]

162. Buie, T.; Campbell, D.B.; Fuchs, G.J.; Furuta, G.T.; Levy, J.; VandeWater, J.; Whitaker, A.H.; Atkins, D.; Bauman, M.L.; Beaudet, A.L.; et al. Evaluation, diagnosis, and treatment of gastrointestinal disorders in individuals with asds: A consensus report. Pediatrics 2010, 125, S1-S8. [CrossRef] [PubMed]

163. Adams, J.B.; Johansen, L.J.; Powell, L.D.; Quig, D.; Rubin, R.A. Gastrointestinal flora and gastrointestinal status in children with autism-comparisons to typical children and correlation with autism severity. BMC Gastroenterol. 2011, 11, 22. [CrossRef] [PubMed]

164. Navarro, F.; Liu, Y.; Rhoads, J.M. Can probiotics benefit children with autism spectrum disorders? World J. Gastroenterol. 2016, 22, 10093. [CrossRef]

165. De Angelis, M.; Piccolo, M.; Vannini, L.; Siragusa, S.; De Giacomo, A.; Serrazzanetti, D.I.; Cristofori, F.; Guerzoni, M.E.; Gobbetti, M.; Francavilla, R. Fecal microbiota and metabolome of children with autism and pervasive developmental disorder not otherwise specified. PLoS ONE 2013, 8, e76993. [CrossRef]

166. Lefranc-Millot, C.; Guérin-Deremaux, L.; Wils, D.; Neut, C.; Miller, L.; Saniez-Degrave, M. Impact of a resistant dextrin on intestinal ecology: How altering the digestive ecosystem with nutriose ${ }^{\circledR}$, a soluble fibre with prebiotic properties, may be beneficial for health. J. Int. Med. Res. 2012, 40, 211-224. [CrossRef]

167. Nankova, B.B.; Agarwal, R.; MacFabe, D.F.; La Gamma, E.F. Enteric bacterial metabolites propionic and butyric acid modulate gene expression, including creb-dependent catecholaminergic neurotransmission, in pc12 cells-possible relevance to autism spectrum disorders. PLoS ONE 2014, 9, e103740. [CrossRef]

168. Müller, J.B.; Guggenheim, P.; Haemmerli, U. Treatment of chronic portal-systemic encephalopathy with lactulose. Lancet 1966, 287, 890-893. [CrossRef]

169. Prasad, S.; Dhiman, R.K.; Duseja, A.; Chawla, Y.K.; Sharma, A.; Agarwal, R. Lactulose improves cognitive functions and health-related quality of life in patients with cirrhosis who have minimal hepatic encephalopathy. Hepatology 2007, 45, 549-559. [CrossRef] [PubMed]

170. Shukla, S.; Shukla, A.; Mehboob, S.; Guha, S. Meta-analysis: The effects of gut flora modulation using prebiotics, probiotics and synbiotics on minimal hepatic encephalopathy. Aliment. Pharmacol. Ther. 2011, 33, 662-671. [CrossRef] [PubMed]

171. Elkington, S.; Floch, M.; Conn, H. Lactulose in the treatment of chronic portal-systemic encephalopathy: A double-blind clinical trial. N. Engl. J. Med. 1969, 281, 408-412. [CrossRef] [PubMed]

172. Blanc, P.; Daures, J.P.; Rouillon, J.M.; Peray, P.; Pierrugues, R.; Larrey, D.; Gremy, F.; Michel, H. Lactitol or lactulose in the treatment of chronic hepatic encephalopathy: Results of a meta-analysis. Hepatology 1992, 15, 222-228. [CrossRef] [PubMed]

173. Cammà, C.; Fiorello, F.; Tinè, F.; Marchesini, G.; Fabbri, A.; Pagliaro, L. Lactitol in treatment of chronic hepatic encephalopathy. Digest. Dis. Sci. 1993, 38, 916-922. [CrossRef] [PubMed]

174. Weber, F., Jr. Lactulose and combination therapy of hepatic encephalopathy: The role of the intestinal microflora. Digest. Dis. 1996, 14, 53-63. [CrossRef]

175. Hong, K.-B.; Jeong, M.; Han, K.S.; Hwan Kim, J.; Park, Y.; Suh, H.J. Photoprotective effects of galacto-oligosaccharide and/or bifidobacterium longum supplementation against skin damage induced by ultraviolet irradiation in hairless mice. Int. J. Food Sci. Nutr. 2015, 66, 923-930. [CrossRef]

176. Kawakami, K.; Makino, I.; Asahara, T.; Kato, I.; Onoue, M. Dietary galacto-oligosaccharides mixture can suppress serum phenol and p-cresol levels in rats fed tyrosine diet. J. Nutr. Sci. Vitaminol. 2005, 51, 182-186. [CrossRef] 
177. Mitsuyoshi, K.; Masuoka, N.; Chiaki, K.; Sugimoto, S.; Iizuka, R.; Manabe, K.; Toshiro, S.; Kazutoshi, O.; Nonaka, C.; Miyazaki, K.; et al. Consecutive intake of fermented milk containing bifidobacterium breve strain yakult and galacto-oligosaccharides benefits skin condition in healthy adult women. Biosci. Microbiot. Food Health 2013, 32, 33-39.

178. Miyazaki, K.; Masuoka, N.; Kano, M.; Iizuka, R. Bifidobacterium fermented milk and galacto-oligosaccharides lead to improved skin health by decreasing phenols production by gut microbiota. Benef. Microbes 2013, 5, 121-128. [CrossRef] [PubMed]

179. Mohkam, M.; Nezafat, N.; Berenjian, A.; Mobasher, M.A.; Ghasemi, Y. Identification of bacillus probiotics isolated from soil rhizosphere using 16 s rrna, reca, rpob gene sequencing and rapd-pcr. Probiot. Antimicrob. Proteins 2016, 8, 8-18. [CrossRef] [PubMed]

180. Mohkam, M.; Rasoul-Amini, S.; Shokri, D.; Berenjian, A.; Rahimi, F.; Sadraeian, M.; Khalvati, B.; Gholami, A.; Ghasemi, Y. Characterization and in vitro probiotic assessment of potential indigenous bacillus strains isolated from soil rhizosphere. Minerva Biotechnol. 2016, 28, 19-28.

181. Mozaffarian, D.; Benjamin, E.; Go, A.; Arnett, D.K.; Blaha, M.J.; Cushman, M.; Das, S.R.; Sarah de Ferranti, M.; Després, J.-P.; Fullerton, H.J.; et al. Aha statistical update. Heart Dis. Stroke 2015, 131, 29-322.

182. Letexier, D.; Diraison, F.; Beylot, M. Addition of inulin to a moderately high-carbohydrate diet reduces hepatic lipogenesis and plasma triacylglycerol concentrations in humans. Am. J. Clin. Nutr. 2003, 77, 559-564. [CrossRef] [PubMed]

183. Russo, F.; Chimienti, G.; Riezzo, G.; Pepe, G.; Petrosillo, G.; Chiloiro, M.; Marconi, E. Inulin-enriched pasta affects lipid profile and lp (a) concentrations in italian young healthy male volunteers. Eur. J. Nutr. 2008, 47, 453-459. [CrossRef]

184. Forcheron, F; Beylot, M. Long-term administration of inulin-type fructans has no significant lipid-lowering effect in normolipidemic humans. Metabolism 2007, 56, 1093-1098. [CrossRef]

185. Vogt, J.A.; Ishii-Schrade, K.B.; Pencharz, P.B.; Jones, P.J.; Wolever, T.M. L-rhamnose and lactulose decrease serum triacylglycerols and their rates of synthesis, but do not affect serum cholesterol concentrations in men. J. Nutr. 2006, 136, 2160-2166. [CrossRef]

186. Jenkins, D.; Wolever, T.; Jenkins, A.; Brighenti, F.; Vuksan, V.; Rao, A.V.; Cunnane, S.C.; Ocana, A.; Corey, P.; Vezina, C. Specific types of colonic fermentation may raise low-density-lipoprotein-cholesterol concentrations. Am. J. Clin. Nutr. 1991, 54, 141-147. [CrossRef]

187. Vulevic, J.; Juric, A.; Tzortzis, G.; Gibson, G.R. A mixture of trans-galactooligosaccharides reduces markers of metabolic syndrome and modulates the fecal microbiota and immune function of overweight adults. J. Nutr. 2013, 143, 324-331. [CrossRef]

188. Tiwari, U.; Cummins, E. Meta-analysis of the effect of $\beta$-glucan intake on blood cholesterol and glucose levels. Nutrition 2011, 27, 1008-1016. [CrossRef] [PubMed]

189. Brighenti, F. Dietary fructans and serum triacylglycerols: A meta-analysis of randomized controlled trials. J. Nutr. 2007, 137, 2552S-2556S. [CrossRef] [PubMed]

190. Beynen, A.C.; Buechler, K.F.; Van der Molen, A.J.; Geelen, M.J. The effects of lactate and acetate on fatty acid and cholesterol biosynthesis by isolated rat hepatocytes. Int. J. Biochem. 1982, 14, 165-169. [CrossRef]

191. Wolever, T.; Brighenti, F.; Royall, D.; Jenkins, A.L.; Jenkins, D.J. Effect of rectal infusion of short chain fatty acids in human subjects. Am. J. Gastroenterol. 1989, 84, 1027-1033. [PubMed]

192. Wolever, T.; Spadafora, P.J.; Cunnane, S.C.; Pencharz, P.B. Propionate inhibits incorporation of colonic [1, 2-13c] acetate into plasma lipids in humans. Am. J. Clin. Nutr. 1995, 61, 1241-1247. [CrossRef] [PubMed]

193. Mortensen, P.B.; Holtug, K.; Rasmussen, H.S. Short-chain fatty acid production from mono-and disaccharides in a fecal incubation system: Implications for colonic fermentation of dietary fiber in humans. J. Nutr. 1988, 118, 321-325. [CrossRef] [PubMed]

194. Lambert, J.E.; Parnell, J.A.; Eksteen, B.; Raman, M.; Bomhof, M.R.; Rioux, K.P.; Madsen, K.L.; Reimer, R.A. Gut microbiota manipulation with prebiotics in patients with non-alcoholic fatty liver disease: A randomized controlled trial protocol. BMC Gastroenterol. 2015, 15, 169. [CrossRef] [PubMed]

195. Tarantino, G.; Finelli, C. Systematic review on intervention with prebiotics/probiotics in patients with obesity-related nonalcoholic fatty liver disease. Future Microbiol. 2015, 10, 889-902. [CrossRef]

196. Cashman, K. Calcium intake, calcium bioavailability and bone health. Br. J. Nutr. 2002, 87, S169-S177. [CrossRef] 
197. Carlson, J.L.; Erickson, J.M.; Lloyd, B.B.; Slavin, J.L. Health effects and sources of prebiotic dietary fiber. Curr. Dev. Nutr. 2018, 2, nzy005. [CrossRef]

198. Ellegård, L.; Andersson, H.; Bosaeus, I. Inulin and oligofructose do not influence the absorption of cholesterol, or the excretion of cholesterol, ca, $\mathrm{mg}$, $\mathrm{zn}$, fe, or bile acids but increases energy excretion in ileostomy subjects. Eur. J. Clin. Nutr. 1997, 51, 1-5. [CrossRef] [PubMed]

199. Van den Heuvel, E.; Schaafsma, G.; Muys, T.; van Dokkum, W. Nondigestible oligosaccharides do not interfere with calcium and nonheme-iron absorption in young, healthy men. Am. J. Clin. Nutr. 1998, 67, 445-451. [CrossRef] [PubMed]

200. Tahiri, M.; Tressol, J.C.; Arnaud, J.; Bornet, F.R.; Bouteloup-Demange, C.; Feillet-Coudray, C.; Brandolini, M.; Ducros, V.; Pépin, D.; Brouns, F.; et al. Effect of short-chain fructooligosaccharides on intestinal calcium absorption and calcium status in postmenopausal women: A stable-isotope study. Am. J. Clin. Nutr. 2003, 77, 449-457. [CrossRef] [PubMed]

201. López-Huertas, E.; Teucher, B.; Boza, J.J.; Martínez-Férez, A.; Majsak-Newman, G.; Baró, L.; Carrero, J.J.; González-Santiago, M.; Fonollá, J.; Fairweather-Tait, S. Absorption of calcium from milks enriched with fructo-oligosaccharides, caseinophosphopeptides, tricalcium phosphate, and milk solids. Am. J. Clin. Nutr. 2006, 83, 310-316. [CrossRef] [PubMed]

202. Van Den Heuvel, E.G.; Muijs, T.; Van Dokkum, W.; Schaafsma, G. Lactulose stimulates calcium absorption in postmenopausal women. J. Bone Miner. Res. 1999, 14, 1211-1216. [CrossRef] [PubMed]

203. van den Heuvel, E.G.; Schoterman, M.H.; Muijs, T. Transgalactooligosaccharides stimulate calcium absorption in postmenopausal women. J. Nutr. 2000, 130, 2938-2942. [CrossRef] [PubMed]

204. Abrams, S.A.; Griffin, I.J.; Hawthorne, K.M.; Liang, L.; Gunn, S.K.; Darlington, G.; Ellis, K.J. A combination of prebiotic short-and long-chain inulin-type fructans enhances calcium absorption and bone mineralization in young adolescents. Am. J. Clin. Nutr. 2005, 82, 471-476. [CrossRef]

205. Griffin, I.; Davila, P.; Abrams, S. Non-digestible oligosaccharides and calcium absorption in girls with adequate calcium intakes. Br. J. Nutr. 2002, 87, S187-S191. [CrossRef]

206. Svensson, U.; Håkansson, J. Safety of Food and Beverages: Safety of Probiotics and Prebiotics; Elsevier: New York, NY, USA, 2014.

207. Garg, B.D.; Balasubramanian, H.; Kabra, N.S. Physiological effects of prebiotics and its role in prevention of necrotizing enterocolitis in preterm neonates. J. Matern.-Fetal Neonatal Med. 2018, 31, 2071-2078. [CrossRef]

208. Tsai, Y.-L.; Lin, T.-L.; Chang, C.-J.; Wu, T.-R.; Lai, W.-F.; Lu, C.-C.; Lai, H.-C. Probiotics, prebiotics and amelioration of diseases. J. Biomed. Sci. 2019, 26, 3. [CrossRef] 